\title{
Review Article \\ Foam Concrete: A State-of-the-Art and State-of-the-Practice Review
}

\author{
Yanbin Fu $\mathbb{D},{ }^{1,2,3}$ Xiuling Wang $\mathbb{D},^{2}$ Lixin Wang $\mathbb{D},{ }^{2,4}$ and Yunpeng $\mathrm{Li}^{1}$ \\ ${ }^{1}$ College of Civil and Transportation Engineering, Shenzhen University, Shenzhen, Guangdong 518060, China \\ ${ }^{2}$ Key Laboratory for Special Area Highway Engineering of Ministry of Education, Chang'an University, Xi'an, \\ Shaanxi 710064, China \\ ${ }^{3}$ Underground Polis Academy of Shenzhen University, Shenzhen, Guangdong 518060, China \\ ${ }^{4}$ State Key Laboratory of Rail Transit Engineering Informatization, China Railway First Survey and Design, \\ Institute Group Co., Ltd., Xi'an, Shaanxi 710043, China
}

Correspondence should be addressed to Xiuling Wang; wangxiuling@chd.edu.cn

Received 21 October 2019; Revised 20 December 2019; Accepted 29 January 2020; Published 26 March 2020

Academic Editor: Ivan Giorgio

Copyright (c) 2020 Yanbin Fu et al. This is an open access article distributed under the Creative Commons Attribution License, which permits unrestricted use, distribution, and reproduction in any medium, provided the original work is properly cited.

Foam concrete (FC) has the potential of being an alternative to ordinary concrete, as it reduces dead loads on the structure and foundation, contributes to energy conservation, and lowers the cost of production and labor cost during the construction and transportation. The paper reports a state-of-the-art review of foam concrete in terms of its components, manufacturing and material properties like drying shrinkage, compressive strength, stability and pore structure, etc. In view of the significance of the FC in engineering construction, it also includes a state-of-the-practice review of foam concrete in tunnel and underground engineering. Some shortcomings and technical limitations as well as emerging direction for performance enhancement of FC are also discussed. Current review concludes that the long-term performance and enhancement-associated properties need to be deeply investigated. This study can help alleviate consumer concerns and further encourage the wider application of FC in civil engineering.

\section{Introduction}

FC is a type of cement mortar containing cement, water, and stable and homogeneous foam introduced using a suitable foaming agent [1-3], which can be regarded as self-compacting materials [4]. Other academic terms describing this material are lightweight cellular concrete [5], low-density foam concrete, or cellular lightweight concrete, etc. [6-8]. In practice, it provides satisfactory solutions to address various challenges and problems faced in construction activities. Fewer chemicals containing in this material well meets the sustainable and environmental demands, and sometimes, it can be partially or even entirely substituted for normal concrete $[9,10]$. The textural surface and microstructural cells make it widely used in the fields of the thermal insulation $[11,12]$, sound absorbance $[13,14]$, and fire resistance $[15,16]$. A great number of environmentally friendly buildings using FC as nonstructural members have been built in recent years $[17,18]$. It is also used for bridge abutment filling to eliminate differential settlement [19]. In addition, the applications for prefabricated components production [20], building foundation [21-23], and airport buffer system are also reported [24]. Foam concrete has been commonly used in construction applications in different countries such as Germany, USA, Brazil, UK, and Canada [25].

This material has renewed interests in terms of underground engineering. This is the requirement of underground structure to control the overlying dead load [26-34], whereas the controllable density and low self-weight $[35,36]$ could be effectively used for reducing the dead load. Other properties, such as seismic resistance, ideal coordinated deformation capacity, and easy pumping, also contribute to enhance the popularity of this material $[37,38]$. Nowadays, the FC has been quickly promoted as construction materials for tunnels and underground works. Its excellent self- 
flowing capacity can be used to fill voids, sink holes, disused sewage pipes, abandoned subways, and so on. The low and controlled self-weight makes it capable for load reduction or liner elements in tunnel and metro systems [39-41].

Though there are limited studies regarding the practical applications of FC in civil engineering, its properties have been deeply studied. For example, Tan et al. [42] performed an investigation on compression deformation properties of FC used as liner element for the purpose of further explaining stress and strain response. The experimental results indicated that the compressive strength of FC increases with density and confining pressure, whereas the modulus of elasticity has a positive correlation only with densities regardless of confining pressure. And no notable correlation was observed between peak strain and density, but peak strain increases with confining pressure. Tikalsky et al. [43] studied the freeze-thaw durability of cellular concrete and proposed an improved freeze-thaw test method. They reported that depth of absorption was considered as a critical predictor in developing freeze-thawresistant concrete, which will contribute to promote effectiveness in terms of using FC as insulation material for tunnels in cold regions. Sun et al. [44] explored the influence of different foaming agents on compressive strength, drying shrinkage, and workability of FC, which will be helpful to determine specification and implementation details. Moreover, Amran et al. [37] reviewed the composition, preparation process, and properties of FC, while the focus of a review organized by Ramamurthy et al. [38] is to classify literatures on foaming materials, foaming agents, cement, fillers, mix proportion, production methods, fresh and hardened properties of FC, etc. Significant progress of FC application has been made over the past few decades. In Canada, cement-based FC has been widely used for tunnel grouting [45]. Zhao et al. [46] developed a foam cementbased material as a sacrificial tunnel lining structural cladding used under the situation of blasting load action. This FC-based sacrificial cladding with the optimized thickness effectively alleviates the dynamic responses induced by blasting loads in tunnel. Choi and Ma [47] employed lightweight FC to facilitate tunnel drainage, whereas it was successfully implemented in a two-lane highway tunnel in South Korea. Successful application was achieved due to the effective formation and distribution of open-cell foams, with excellent permeability.

With the booming development of FC and manufacturing technology, FC application in tunnels and underground works has revealed prominent prospects. This review briefly describes the history and development of FC, and some forwardlooking perspectives are also discussed. The FC engineering properties and benefits to engineering construction are elaborated. The objective of this review is to highlight engineering properties, material properties, and the practical applications in tunnel and underground engineering.

\section{Foam Concrete}

2.1. History and Recent Development. There is a confusion existed between FC and similar materials in early literatures, i.e., aerated concrete and air-entrained concrete [48]. However, one definition (i.e., FC is defined as a cementing material with the minimum of $20 \%$ foams by volume in the mixed plastic mortar) introduced by Van Dijk [49] clearly distinguish the FC from aerated concrete $[50,51]$ and airentrained concrete [52]. The closed air-voids system in FC notably reduces its density and weight and at the same time produces efficient insulation and fire resistance capacity $[26,53]$.

The first Portland cement-based FC was patented by Axel Eriksson in 1923, and then, small-scale commercial production activities were launched [54]. Valora carried out the first comprehensive investigation in the 1950s [55]. Rudnai [56] and Short and Kinniburgh [57] systematically reported the composition, properties, and applications of the FC later. FC was initially envisaged as a void filling, stabilization, and insulation material [58]. The booming development of this new constituent material in buildings and constructions was enhanced in the late 1970s [59]. A government-oriented assessment on FC could be seen as a milestone event to further widening FC applications.

Over the past 30 years, FC are widely used for the bulk filling [38], ditch repair, retaining wall [60], bridge abutment backfill [17], slab structure of concrete floor [18], and housing insulation [37], etc. (Figure 1). Currently, people are increasingly interested in using it as a nonstructure or semistructure member for underground engineering, such as grouting works for tunnels, damage treatment, and liner structures.

2.2. Material Components and Preparation. The basic components of FC consist of (1) water, (2) binder, (3) foaming agent, (4) filler, (5) additive, and (6) fiber. The stateof-the-art research and findings on these components to date are described as follows:

Water: The water requirement for constituent material depends on composition, consistency and stability of the mortar body [38]. The lower water content leads to a hard mixture, which easily resulting in bubble bursting [61]. The higher water content causes mixture too thin to accommodate bubbles, thereby causing bubbles separating from the mixture [1]. The American Concrete Institute (ACI) recommends that mixed water should be fresh, clean, and drinkable [62]. Sometimes, the mixed water can be replaced by equivalent-performance water received from municipal sectors in case the strength FC could reach $90 \%$ within specified curing time [38].

Binder: Cement is the most commonly used binder. The ordinary Portland cement, rapid hardening Portland cement, calcium sulphoaluminate cement, and highalumina can be used in ranges between 25\% and 100\% of the binder content $[59,63]$.

Foaming agent: The foaming agent determines FC density by controlling generation rate of the bubbles in cement paste. The resin-based was one of the earliest used foaming agents in FC. So far, synthetic, protein- 


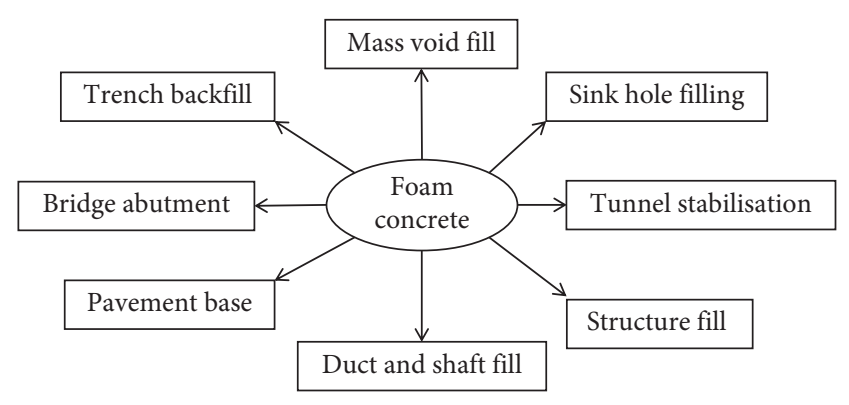

Figure 1: Different applications of FC.

based, composite and synthetic surfactants have been derived and developed, while the most frequently used are synthetic and protein-based ones [64].

Filler: Various fillers such as silica fume, fly ash, limestone powder, granulated blast furnace slag, and fly-ash ceramicite [61] have been widely adopted for the purpose to enrich FC mechanical performances [65-67]. Addition of these fillers is helpful to improve mix proportion design, long-term strength, and reduce costs. In addition, some fine aggregates such as fine sand [68], recycled glass powder [69], and surface modified chip [70] are commonly used for production of high-density FC.

Additive: Commonly used additive includes the water reducer, water-proofing additive, retarder, coagulation accelerator, etc. Plasticizers are always considered to enhance compatibility [43]. In fact, they are defined as water reducers to improve performance of fresh concrete by reducing fluidity and plasticity, and there is no notable impact on concrete segregation was observed $[71,72]$.

Fiber: A variety of fibers are added into FC so as to improve strength and reduce shrinkage. They are mainly polypropylene $[73,74]$, glass and polypropylene [75], red ramie [76, 77], palm oil, steel [78], coconut [79], waste paper cellulose [80], carbon, and polypropylene [81], which usually introduced in ranges between $0.2 \%$ and $1.5 \%$ of the mixture volume.

FC is commonly prepared by prefoaming method or mixfoaming method [37]. The majority of common mixers such as the inclined drum, pan mixer used for concrete, or mortar is applicable to FC production. The mixer type, mix proportion, and mixing order used for FC depend on adoption of the above-mentioned two methods [38]. The major procedures using these two methods are presented as below:

Prefoaming Method. (1) The foam and base mixture are prepared independently. (2) Totally mix the foam and base mixture [82].

Mix-Foaming Method. (1) Surfactants or foaming agent are mixed with base mixture together (especially the cement paste). (2) The foam produces cellular structures in FC.

There are two ways, i.e., dry or wet process, used for bubble generation. The dry process produces more stable bubbles with sizes less than $1 \mathrm{~mm}$ compared to the wet process, for which the sizes of the generated bubbles are between $2 \mathrm{~mm}$ and $5 \mathrm{~mm}$. The stable foam helps to resists mortar pressure until cement solidifies, which is advantageous to generate reliable pore structure in FC [83].

Though the mixing process and FC quality in these two methods can be controlled, the preforming method is considered superior to mix-forming method due to the following [84].

(1) Lower requirements for foaming agents [55]

(2) The foaming agent content is closely related to air content in mixture

2.3. Material Properties. Currently, weakness and poor durability on FC still exist. The discussion on the material properties in this section is mainly based on practical applications, where there are potential problems such as (1) underground water, (2) insufficient structure strength, (3) structure crack/failure, (4) stabilization issue, and (5) corrosion. The material properties like drying shrinkage, compressive strength, and durability, are discussed through literature review.

2.3.1. Drying Shrinkage. Lack of coarse aggregates leads to 4-10 times higher shrinkage of the FC than that observed in ordinary concrete $[15,37]$. There are many factors affecting the drying shrinkage, such as density, foaming agent, filler, additive, and moisture contents. Table 1 presents different drying shrinkage values observed in some cement-based materials.

In general, drying shrinkage decreases with the density reduction [37]. The shrinkage differences induced by foaming agents are bound up with pore structure of FC, and the lower pore connectivity helps to reduce the drying shrinkage [44]. Jones et al. [86] observed the decrease of drying shrinkage when fine sand was used as fillers instead of fly ash, because the fine sand provides a superior capacity in resisting shrinkage deformation. Many findings demonstrate that fine aggregate such as light ceramsite [87], expanded perlite, vitrified microsphere [88], and magnesium expansive agent [89] together with reduction of foam volume [90] can reduce drying shrinkage. Meanwhile, restrictive effects from increase of water and aggregate also provide support for drying shrinkage reduction [91].

It is reported that autoclaving technique reduces $12-50 \%$ drying shrinkage and brings a strength enhancement; therefore, autoclaving is an ideal option for maintaining FC products within an acceptable strength and shrinkage level [15]. To reduce drying shrinkage, some aspects like water content control, selection of binder and foaming agent as well as mixture modifying with fine aggregate are worthy of further studies. The use of fibers can significantly enhance resistance capacity on drying shrinkage due to (1) tensile strength improvement of cement base mixture, (2) prevention of further cracks development in cement base mixture, and (3) capacity improvement of resisting deformation. Table 2 summarizes and reviews different results and findings on the drying shrinkage. 
TABLE 1: The drying shrinkage values observed in typical cement-based materials [85].

\begin{tabular}{lcccc}
\hline Material & Cement paste & Cement mortar & Cement concrete & FC \\
\hline Drying shrinkage (\%) & $0.15-0.3$ & $0.08-0.2$ & $0.06-0.09$ & $0.15-0.35$ \\
\hline
\end{tabular}

TABLE 2: Review of filler, foaming agent, and additive used in FC, and the resulting density ranges and drying shrinkage.

\begin{tabular}{|c|c|c|c|c|c|c|}
\hline Filler & Foaming agent & $w / c$ ratio & Additive & $\begin{array}{l}\text { Density } \\
\left(\mathrm{kg} / \mathrm{m}^{3}\right)\end{array}$ & $\begin{array}{c}\text { Drying } \\
\text { shrinkage } \\
(\%)\end{array}$ & Reference \\
\hline $\begin{array}{l}\text { Blast-furnace } \\
\text { slag + limestone fine }\end{array}$ & Fatty alcohol-based liquid & 0.29 & $\begin{array}{c}\text { Magnesium expansive } \\
\text { agent }+ \text { calcium sulfoaluminate }\end{array}$ & $1611-1638$ & $\begin{array}{c}0.05-0.32 \\
28 \mathrm{~d}\end{array}$ & [89] \\
\hline Polymer fiber & Foamin $C^{@}$ & 0.3 & Viscosity enhancing agent & $380-830$ & $0.1-0.49$ & {$[92]$} \\
\hline $\mathrm{N} / \mathrm{A}$ & $\begin{array}{c}\text { Animal } \\
\text { based }+ \text { synthetic }+ \text { plant } \\
\text { based surfactants }\end{array}$ & 0.5 & N/A & 600 & $\begin{array}{c}0.25-0.3 \\
90 \mathrm{~d}\end{array}$ & {$[44]$} \\
\hline Crushed sand + FA & Hydrogen peroxide & 0.3 & $\mathrm{Na}_{2} \mathrm{SiO}_{3}+\mathrm{NaOH}$ & $1889-2106$ & $\begin{array}{c}0.09-0.1 \\
180 \mathrm{~d}\end{array}$ & {$[93]$} \\
\hline FA + natural sand & Protein foaming agent & $0.71-2.22$ & $\mathrm{~N} / \mathrm{A}$ & $1000-1400$ & $\begin{array}{l}0.09-0.2 \\
365 \mathrm{~d}\end{array}$ & {$[94]$} \\
\hline $\mathrm{N} / \mathrm{A}$ & Synthetic polymeric latex & $0.45-0.6$ & $\mathrm{~N} / \mathrm{A}$ & $260-800$ & $0.18-0.31$ & [95] \\
\hline N/A & Synthetic based & $0.52-0.75$ & N/A & $300-800$ & $\begin{array}{l}0.26-0.35 \\
\quad 90 \mathrm{~d}\end{array}$ & {$[96]$} \\
\hline Sand & Hydrolyzed protein & 0.5 & $\mathrm{~N} / \mathrm{A}$ & $900-1100$ & $\begin{array}{l}0.7-0.72 \\
28 \mathrm{~d}\end{array}$ & {$[97]$} \\
\hline Quartz sand & PB-2000 & $\mathrm{N} / \mathrm{A}$ & Microreinforcing additive & N/A & $0.15-0.3$ & {$[98]$} \\
\hline FA & Organic based & $0.3-0.5$ & $\mathrm{Na}_{2} \mathrm{SO}_{4}+$ Triethanolamine & $400-800$ & $\begin{array}{l}0.09-0.18 \\
28 \mathrm{~d}\end{array}$ & [99] \\
\hline
\end{tabular}

N/A, not available; FA, fly ash.

Some adverse factors such as poor early curing, insufficient water conservation measures, or harsh production conditions may cause water evaporation, thereby leading to shrinkage or even crack in FC. Some technical measures improving these situations are illustrated as following:

(1) Suitable cement dosage.

(2) Lower water-cement ratio.

(3) Strengthen water conservation in early stage.

(4) Use waterproofing agent.

(5) Use crack prevention net.

2.3.2. Compressive Strength. Though FC has been deeply studied, some shortcomings such as low strength still restrict its wider applications [100]. The strength of FC is determined by different cementitious materials, cement dosage, mix proportion, water-cement ratio, foam volume, foaming agent, curing method, additive, etc. [101]. Table 3 illustrates some studies on different factors affecting FC compressive strength.

To a certain extent, the density controls the strength. Hence, it is always to seek a balance between strength and density, for the purpose to maximize strength while reducing density as much as possible. Sometimes, this can be achieved through optimizing cementitious materials and selecting high-quality foaming agents and ultralight aggregates. Nambiar et al. [1, 61] indicated that the filler types determine the water-solid ratios when FC density is constant, and the reduction of sand particle size will help to improve strength.
The foam volume exerts a notable impact on the flow behavior of FC, and a reduction in particle size of filler shows a positive effect on strength improvement of FC. Park et al. [111] added carbon fiber into base mixture so as to produce carbon-fiber-reinforced FC, and they reported that the strength and fracture toughness were obviously improved due to carbon fiber reinforcement effect. The results confirmed that reasonable water-cement ratios exhibit a notable impact on enhancing the strength. The higher water-cement ratio ensures excellent slurry fluidity thereby introducing foam into cement paste with an even distribution, so as to achieve strength growth. On the contrary, the decrease of water cement ratio results in poor fluidity, thus reducing the strength. The dominant factor affecting strength is cement quality added into mortar slurry, whereas the high strength cement is considered as an effective way for strength enhancement. However, it should be added appropriately considering the increase of subsequent cost.

The investigation indicated that FC strength decreases with the voids increase [112-114]. The impact of foaming agent on strength is mainly manifested in aspects of the bubble size, distribution uniformities of bubbles, foam stability, and foaming capacity. Ideally, foaming agents should be characterized by strong foaming capacity, poor water-carrying capacity per unit, and little adverse impacts on FC [115-118]. Attempts and investigations can be considered regarding selection of the high-performance foaming agent so as to prepare the small and uniform bubbles. The experimental results showed that the watercement ratio and air-ash ratio have crucial impacts on FC 
TABle 3: Overview on research on factors affecting compressive strength of FC.

\begin{tabular}{|c|c|c|c|c|}
\hline Composites & $\begin{array}{c}\text { Factors } \\
\text { investigated }\end{array}$ & $28 \mathrm{~d} \mathrm{CS}$ & Main findings and conclusions & Reference \\
\hline OPC & $\begin{array}{l}\text { (i) Curing } \\
\text { condition } \\
\text { (ii) Fiber content } \\
\text { (iii) Dry density }\end{array}$ & $1.56-13.38$ & $\begin{array}{l}\text { (1) Compressive strength increases with dry density increase in nearly } \\
\text { linear, while bending strength increases more obviously. } \\
\text { (2) The flexural strength was significantly increased when fiber content } \\
\text { increased to a certain extent, but the compressive strength was not } \\
\text { significantly affected. }\end{array}$ & [92] \\
\hline Cement, sand & $\begin{array}{l}\text { (i) Coconut fiber } \\
\text { content }\end{array}$ & $9.6-14.6$ & $\begin{array}{l}\text { (1) The volume increase of coconut fiber particle aggregate in FC can } \\
\text { significantly enhance compressive strength with a maximum value of } 15 \% \text {. }\end{array}$ & {$[102]$} \\
\hline OPC & $\begin{array}{l}\text { (i) Water-cement } \\
\text { ratio }\end{array}$ & $3-5.1$ & $\begin{array}{l}\text { (1) The FC compressive strength varies in an inverted V-shape with the } \\
\text { increase of water cement ratio. }\end{array}$ & [103] \\
\hline OPC & $\begin{array}{l}\text { (i) Bentonite slurry } \\
\text { content }\end{array}$ & $3-4.7$ & $\begin{array}{l}\text { (1) The compressive strength decreases with mixing content increase of } \\
\text { bentonite slurry. }\end{array}$ & {$[104]$} \\
\hline OPC, GBFS, FA & (i) Foam stabilizer & $1.7-2.3$ & $\begin{array}{l}\text { (1) XG stabilizer performs positively on thermal conductivity and } \\
\text { compressive strength of FC. } \\
\text { (2) The compressive strength with mechanical and chemical foaming } \\
\text { increased by } 34 \% \text { and } 20 \% \text {, respectively. }\end{array}$ & {$[105]$} \\
\hline OPC & $\begin{array}{l}\text { (i) Foaming agents } \\
\text { (ii) Dry densities } \\
\text { (iii) Cement type }\end{array}$ & $0.20-11.74$ & $\begin{array}{l}\text { (1) The compressive strength increases more obviously when protein based } \\
\text { foaming agent is used in mix design as its positive effect on pores. } \\
\text { (2) The maximum strength value was recorded in cellophane curing while } \\
\text { the minimum one was found in air curing. }\end{array}$ & [7] \\
\hline OPC & $\begin{array}{l}\text { (i) Aggregate } \\
\text { substitution }\end{array}$ & $3-48$ & $\begin{array}{c}\text { (1) Slag partially substituted for fly ash improves FC strength at room } \\
\text { temperature, but leads to a drying shrinkage and strength loss at high } \\
\text { temperature. }\end{array}$ & [19] \\
\hline $\begin{array}{l}\text { Cement, natural } \\
\text { sand }\end{array}$ & (i) Additive types & $6-47$ & $\begin{array}{l}\text { (1) The reinforcement of pore structure and microstructure improvement } \\
\text { of cement paste are helpful to improve FC strength. } \\
\text { (2) The combination of additives reduces size and connectivity of pores } \\
\text { and prevents them from merging as well as produces narrower pores } \\
\text { distribution, and achieves higher strength. }\end{array}$ & [106] \\
\hline OPC & $\begin{array}{l}\text { (i) Different sand } \\
\text { grading }\end{array}$ & $5.6-7.0$ & $\begin{array}{l}\text { (1) The samples prepared with } 0.60 \mathrm{~mm} \text { sand have the highest compressive } \\
\text { strength compared to those prepared with coarse sand grade. } \\
\text { (2) The whole water curing provides a better development environment for } \\
\text { strength increase compared to the air curing. }\end{array}$ & [107] \\
\hline OPC & $\begin{array}{l}\text { (i) Different } \\
\text { pumice types }\end{array}$ & $0.5-3.5$ & $\begin{array}{l}\text { (1) The pumice-based FC has the highest compressive strength. } \\
\text { (2) The density-based empirical model for compressive strength prediction } \\
\text { was proposed. }\end{array}$ & {$[5]$} \\
\hline OPC, fine sand, & $\begin{array}{l}\text { (i) Different filler } \\
\text { types }\end{array}$ & $4-23$ & $\begin{array}{l}\text { (1) Adding superfine GGBS as a partial substitute for cement can increase } \\
\text { strength slightly without significantly changing mix and workability. } \\
\text { (2) The strength with small pore diameter and uniform pore size is higher } \\
\text { than other samples. }\end{array}$ & [108] \\
\hline OPC & $\begin{array}{l}\text { (i) Recycled waste } \\
\text { as filler }\end{array}$ & $1.53-10.26$ & $\begin{array}{l}\text { (1) Recycled glass-filled FC has higher compressive strength compared to } \\
\text { that filled with plastic. } \\
\text { (2) The addition of superplasticizer reduces the amount of macropore and } \\
\text { greatly improves the strength. }\end{array}$ & [109] \\
\hline OPC, sand & $\begin{array}{l}\text { (i) Recycled waste } \\
\text { as filler }\end{array}$ & $5.2-6.8$ & $\begin{array}{l}\text { (1) Compared with FC produced with } 100 \% \text { addition of river sand, using } \\
\text { refined mineral powder as filler can improve compressive strength and } \\
\text { strength performance index. }\end{array}$ & {$[110]$} \\
\hline
\end{tabular}

strength $[119,120]$; it also reported that addition of fibers is helpful to increase strength $[73,74,121]$. The prediction models on compressive strength were also investigated by some researchers. These findings are mainly based on the artificial neural network [122-124], extreme learning machine [125], and regression analysis based empirical models [126]. Table 4 summarizes the prediction models for compressive strength of FC to date.

2.3.3. Durability. The underground members are usually faced with various adverse conditions such as temperature change, freeze-thaw cycles, and acid-base corrosion. These factors may lead to a poor durability of the FC-based structures and members, resulting in structural damages, which seriously affects project safety.

(1) Permeability. Water absorption of FC is attributed to the capillary pore infiltration and connected pore infiltration. Cox and Van Dijk [134] reported that the water absorption of FC was higher than that observed in other concrete types due to the least $20 \%$ foam embedded in plastic mortar. This capacity is generally twice than that of the normal concrete with the same water-binder ratio [63]. An investigation conducted by Nyame [135] found that permeability of concrete mortar 
TABle 4: Prediction models for compressive strength of FC.

\begin{tabular}{|c|c|c|c|c|}
\hline No. & Components & Equations & Annotations & Reference \\
\hline 1 & $\begin{array}{l}\text { OPC and } \\
\text { limestone } \\
\text { powder }\end{array}$ & $f_{c}=0.0029 \times \exp (0.0104 \gamma)$ & $\gamma=\operatorname{dry}$ density $\left(\mathrm{kg} / \mathrm{m}^{3}\right)$ & {$[5]$} \\
\hline 2 & $\begin{array}{l}\text { OPC, fine sand } \\
\text { and FA }\end{array}$ & $f_{c}=A(\ln t)^{B}\left(S_{a}\left(m_{c}+m_{m}\right)+m_{s} / \gamma\right)^{C}$ & $\begin{array}{c}A, B \text { and } C=\text { parameter reflecting compressive } \\
\text { strength, hydration rate and porosity of mix, } \\
t=\text { curing time, } S_{a}=\text { empirical constant, } m_{c}, m_{m} \text { and } \\
m_{s}=\text { cement, admixture, fine aggregate dosages per } \\
\text { cubic meter }\end{array}$ & {$[127]$} \\
\hline 3 & $\begin{array}{l}\text { Cement, FA and } \\
\text { slag }\end{array}$ & $f_{c}=A \times \exp \left(a \times p_{1}\right)+B \times \exp \left(b \times p_{2}\right)$ & $\begin{array}{c}a, b=\text { empirical constants, } A, B=\text { fitting constants, } \\
\qquad p_{1}, p_{2}=\text { porosity. }\end{array}$ & {$[128]$} \\
\hline 4 & $\begin{array}{l}\text { Cement, FA and } \\
\text { slag }\end{array}$ & $f_{c}=C \times\left(1-p_{1}\right)^{c}+D \times\left(1-p_{2}\right)^{d}$ & $c, d=$ empirical constants, $C, D=$ fitting constants & [128] \\
\hline 5 & $\mathrm{OPC}$ and FA & $f_{c}=0.0243 \times \exp (0.0083 \gamma)$ & $\gamma=$ dry density $\left(\mathrm{kg} / \mathrm{m}^{3}\right)$ & [12] \\
\hline 6 & Cement and sand & $f_{c}=0.34 \exp [0.0022 c \times(1+(w / \mathrm{cm})+(s / c))]$ & $\begin{array}{c}c=\text { cement content, } w=\mathrm{cm}=\text { water to cementitious } \\
\text { material ratio, } \mathrm{s} / \mathrm{c}=\text { sand-to-cement ratio }\end{array}$ & {$[126]$} \\
\hline 7 & $\begin{array}{l}\text { Cement, sand } \\
\text { and FA }\end{array}$ & $f_{c}=f\left[d_{c}\left(1+0.2 \rho_{c}+s_{v}\right) /\left(1+k_{s}\right)\left(1+s_{w}\right) \rho_{c} \gamma_{w}\right]^{b}$ & $\begin{array}{c}b=\text { empirical constant, } s_{w}=\text { filler-cement ratio by } \\
\text { weight, } s_{v}=\text { filler-cement ratio by volume, } \\
f=\text { theoretical strength of a paste with zero } \\
\text { porosity, } k_{s}=\text { water-solids ratio by weight, } \gamma_{w}=\text { unit } \\
\text { weight of water, } d_{c}=\text { fresh density, } \rho_{c}=\text { specific } \\
\text { gravity of cement }\end{array}$ & {$[114]$} \\
\hline 8 & $\begin{array}{l}\text { Cement, sand } \\
\text { and FA }\end{array}$ & $f_{c}=K\left[2.06 \times \alpha \times V_{c} / 1-V_{f l}-V_{c}(1-\alpha)\right]^{n}$ & $\begin{aligned} V_{c}=\text { volume of cement, } V_{f l} & =\text { fillers volume per } \\
\text { cubic meter of concrete, } \alpha & =\text { hydration degree, } \\
K=\text { gel intrinsic strength, } n & =\text { empirical constant }\end{aligned}$ & {$[114]$} \\
\hline 9 & Cement and FA & $f_{c}=f\left(-0.324+1.325 \alpha_{d}\right)^{2}$ & $\alpha_{d}=$ dry density ratio & [129] \\
\hline 10 & Cement and FA & $f_{c}=39.6(\ln (t))^{1.174}(1-p)^{3.6}$ & $p=$ porosity & [129] \\
\hline 11 & Cement and ash & $f_{c}=l(a / c)^{2}+m(a / c)+n$ & $\begin{array}{l}a / c=\text { ash/cement ratio by weigth, } l, m \text { and } \\
n=\text { constants }\end{array}$ & {$[130]$} \\
\hline 12 & Cement and FA & $f_{c}=188\left[d_{c}\left(1+0.2 \rho_{c}\right) /\left(1+k_{s}\right) \rho_{c} \gamma_{w}\right]^{3.1}$ & $\begin{array}{c}d_{c}=\text { fresh density, } \rho_{c}=\text { specific gravity of cement, } \\
\gamma_{w}=\text { unit weight of water }\end{array}$ & {$[131]$} \\
\hline 13 & Cement and ash & $f_{c}=1.172 f \alpha_{b}^{3.7}$ & $\begin{array}{c}\alpha_{b}=\text { binder ratio by volume, } f=\text { cement paste } \\
\text { compressive strength }\end{array}$ & {$[63]$} \\
\hline 14 & Cement and sand & $f_{c}=k(c / c+w+a)^{n}$ & $\begin{array}{c}c, w \text {, and } a=\text { absolute volumetric } \\
\text { Proportions of cement, water, and air, } k \text { and } \\
n=\text { constants }\end{array}$ & [119] \\
\hline 15 & Cement & $f_{c}=K_{S} \ln \left(p_{o s} / p\right)$ & $\begin{array}{c}K_{s}=\text { empirical constant, } p_{o s}=\text { porosity at zero- } \\
\text { strength }\end{array}$ & {$[132]$} \\
\hline 16 & Cement & $f_{c}=245\left[d_{c}\left(1+0.2 \rho_{c}\right) /\left(1+K_{s}\right) \rho_{c} \gamma_{w}\right]^{2.7}$ & $\begin{array}{c}\rho_{c}=\text { specific gravity of cement, } \gamma_{w}=\text { unit weight of } \\
\text { water, } K_{s}=\text { empirical constant }\end{array}$ & [133] \\
\hline
\end{tabular}

decreases with porosity decrease after the addition of the aggregate. An increase of the aggregate volume in mixture leads to the increased permeability. Meanwhile, the increase of ash/cement quantity in base mixture proportionally increases the water vapor permeability, especially at low densities [114]. Kearsley et al. [131] studied the influence of different fly ash types on the porosity and permeability. The results showed that dry density directly affects the porosity, but slight impacts of fly ash on porosity were observed. In addition, an empirical model for permeability prediction was proposed:

$$
k_{d}=\frac{G d}{A_{c} t \Delta p},
$$

where $k_{d}$ =vapor flow time rate through unit area, $G=$ weight loss thorough $t$ time in hours, $A_{c}=$ cross sectional-area perpendicular to flow $\left(\mathrm{m}^{2}\right), d=$ thickness of specimen in $m, t=$ time in hour, and $\Delta p=$ distance between dry and moist sides of the specimen.
Different methods were employed by Hilal et al. [136] to investigate effects of pore structure, porosity, and critical pore size on permeability and water absorption of FC. The results showed that the critical pore diameter and the pore diameter size $(>200 \mathrm{~nm})$ decrease with density increase, which is closely related to the permeability. Therefore, the manufacture ability to ensure air being contained in stable, small, and uniform bubbles should be highlighted, which is helpful to reduce the permeability of cement paste due to their integrity and isolation effects.

The adsorption of FC mainly depends on filler types, pore structure, and infiltration mechanism. It was reported that filling effect from mineral aggregates affects the pore structure and permeability of cement paste [137]. Jones and McCarthy [138] compared adsorption differences between sand-based and fly ash-based FC. The results indicated that the fly ash-based mix was endowed with higher water absorption than that mixed with sand. The FC adsorption was generally lower than the corresponding basic mixture and decreases with foam volume 
increase [139]. An investigation conducted by Awang and Ahmad [78] demonstrated that the water absorption dramatically increases owing to the use of steel and polypropylene fibers in the basic mixture. Each kind of fiber has a different surface morphology that plays an important role in the water absorption rate of lightweight FC. Another study suggested that using pozzolanic admixture and turbulent mixing technique can produce water-resistant and durable FC [140].

(2) Frost Resistance. Freeze-thaw cycle is one factor that responsible for deterioration and failure in concrete [141, 142]. An investigation carried out by Tsivilis et al. [143] revealed that addition of limestone powder reduced frost resistance of FC and limestone cement concretes indicate lower resistance to freezing and thawing compared to the pure cement concrete. Tikalsky et al. [43] performed freeze-thaw cycling tests on FC with different mix proportions based on an improved method, and it is found that the compressive strength, initial penetration depth, and water absorption have significant effects on the frost resistance, but little effects of density and permeability on frost resistance are observed.

(3) Carbonization. Carbonization increases the risks of cracking and durability loss of FC [140]. Jones and McCarthy $[59,138]$ also reported that a higher incidence of carbonization was observed in low-density concrete. Compared with fine sand replaced mixture, replacing fly ash with cement in mixture notably improved carbonization resistance capacity [86]. In addition, the foam content increases with decrease of foam density so as to reduce carbonization in FC.

(4) Corrosion. The resistance capacity of FC to erosive environment depends on its cellular structure. However, this structure does not necessarily reduce resistance capacity for water penetration, whereas voids produced cushioning effect to prevent rapid penetration [139]. Sulfate is one of the corrosive agents that affect the service life of FC while the damage risk from alkali-silicon reaction on recycled aggregate is not significant [144]. Sulfate erosion is identified as a complex process and can be influenced by various factors such as cement type, water-cement ratio, exposure time, mineral admixture, permeability, etc. [145-147]. Ranjani and Ramamurthy [148] carried out 12 months of continued assessment on FC performance with variable densities of 1000 to $1500 \mathrm{~kg} / \mathrm{m}^{3}$ by immersing FC examples in sodium sulfate solutions and magnesium sulfate solutions, respectively. The results showed that expansion rate of FC in sodium sulfate environment was $28 \%$ higher than that in magnesium sulfate environment, leading to a $1 \%$ mass loss of specimens in magnesium sulfate environment. In addition, the corrosion resistance capacity of studied samples increases with the decrease of FC density [149].

2.3.4. Thermal Conductivity. Outstanding thermal insulation properties of FC make it popular in the building insulation. It is widely reported in relevant studies that thermal conductivity is an important parameter influencing thermal insulation performance. FC has excellent thermal insulation properties due to its porous structure. The thermal conductivity values are $5-30 \%$ of those measured on normal concrete and range from 0.1 to $0.7 \mathrm{~W} / \mathrm{mK}$ for dry density values of $600-1600 \mathrm{~kg} /$ $\mathrm{m}^{3}$, reducing with decreasing densities [150]. The thermal conductivity of FC is controlled by the filler, density, fiber, mix ratio, temperature, and pore structure.

(1) Influence of Filler. Different aggregates and mineral admixtures have a significant effect on thermal conductivity. It was observed that the addition of the lightweight aggregate in FC reduces the thermal conductivity [151]. It is specified that thermal conductivity value for lightweight aggregate FC with a dry density of $1000 \mathrm{~kg} / \mathrm{m}^{3}$ is $1 / 6$ of that measured on typical cement mortar [152]. Artificially introducing pores into the mortar matrix combining with the use of lightweight aggregate with low particle density has been identified to be helpful for reducing thermal conductivity [91]. FC with a thermal conductivity value of $0.06-0.16 \mathrm{~W} / \mathrm{mK}$ could be produced by moderately filling polystyrene particles into porous mortar [153]. Giannakou and Jones [154] stated that the excellent properties of fly ash, such as low density and hollow particles are advantageous to increase the heat flow paths so as to reduce the thermal conductivity. In a study by Jones and McCarthy [88] reported that typical thermal conductivity values of FC with dry density of $1000-1200 \mathrm{~kg} /$ $\mathrm{m}^{3}$ range between 0.23 and $0.42 \mathrm{~W} / \mathrm{mK}$. And $30 \%$ replacement of cement by PFA (pulverized fuel ash) has also been confirmed to lead to a $12-38 \%$ reduction on thermal conductivity. Studies done by Xie et al. [104] found that use of bentonite slurry improves the thermal insulation performance of FC and observed that with densities of 300 and $600 \mathrm{~kg} / \mathrm{m}^{3}$, the samples with $10 \%$ bentonite slurry underwent the largest reduction in thermal conductivity.

(2) Influence of Density. For FC, it was found that the thermal conductivity reacts proportionally with a density. Weigler and Karl [91] observed a $0.04 \mathrm{~W} / \mathrm{mK}$ drop in total thermal insulation was observed with each $100 \mathrm{~kg} / \mathrm{m} 3$ reduction of the density. The thermal insulation performance decreases as the density volume increases $[155,156]$. In terms of the application of FC in wall brick masonry, an increase up to $23 \%$ on thermal insulation was obtained comparing to the normal concrete when the inner leaf of the wall constructed with the FC at a density of $800 \mathrm{~kg} / \mathrm{m}^{3}$ [111].

(3) Influence of Fiber. Nagy et al. [78] studied the thermal conductivity of several fibers consisting of AR-glass, polypropylene, steel, kenaf, and oil palm fibers. The results showed that the thermal conductivity on samples with steel fiber inclusion is higher than those observed in FC with other fibers inclusion, while polypropylene fiber presented the lowest thermal conductivity. This is explained to be expected because steel fiber itself is a good heat transfer conductor. Also, the higher the fiber inclusion, the higher the thermal conductivity. In another study, Nagy et al. [157] investigated the thermal properties of steel fiber reinforced concrete and observed that the addition of steel fiber does not necessarily increase the thermal conductivity. This is because the addition of fiber leads to the increase of porosity, 
which reduces the density and thermal conductivity. The durability properties of FC consisting of five different synthetic and natural fibers like polypropylene, AR-glass, kenaf, steel, and oil palm fibers were studied by Awang et al. [158]. They confirmed that the maximum reduction in shrinkage and the thermal conductivity was obtained from using polypropylene fibers.

(4) Influence of Mix Ratio. The insulation capacities of FC are proven to be sensitive to the change of mortar-foam ratios [49]. This difference is more obvious in low-density samples ranging between 200 and $300 \mathrm{~kg} / \mathrm{m}^{3}$ [159]. The denser cement paste with a lower water cement ratio is easier to form pores with lager size than that with a higher water cement ratio. Thus, the convective heat transfer in the larger pores under the temperature difference increases the thermal conductivity of the FC with lower water cement ratio [159].

(5) Influence of Temperature. It is reported that the thermal insulation is improved with the decrease of temperature. Richard et al. [160] studied the thermal insulation performance of porous concrete applicated in a low temperature environment, and satisfactory results were observed. At the same time, Richard et al. [161] reviewed the thermal and mechanical properties of $\mathrm{FC}$ in the density range of $640-1440 \mathrm{~kg} / \mathrm{m}^{3}$ with the ambient temperature ranging between 22 and $-196^{\circ} \mathrm{C}$. The results indicated that the thermal conductivity value of foam concrete significantly reduced by $26 \%$ when the temperature falls from 22 to $-196^{\circ} \mathrm{C}$.

(6) Influence of Pore Structure. According to Kumar et al. [162], the thermal conductivity was about $50 \%$ lower than that of normal concrete with a thermal conductivity of $1.43 \mathrm{~W} / \mathrm{mK}$ as a result of the uniform pore size in cellular lightweight concretes (CLCs). FCs with larger size and the wider distribution of bubbles were found to have lower thermal conductivity at low densities [104]. Also, it was shown that higher the porosity, the lower the thermal conductivity. However, the increase of the joint strength of pore paths was found to occasionally increase the thermal conductivity. The location and relative orientation of the pores have a great influence on the thermal conductivity. More thermal resistance was observed when the pores are arranged at right angles to the heat flow, leading to more heat passing through the pores. On the contrary, if a layer of pores is parallel to the direction of heat flow, a smaller thermal resistance will be produced [163].

2.3.5. Pore Structure. A critical task in FC production is to control the nature, size, and distribution of pores, because the pore characteristic is the key factor to determine the density and strength of FC. Pores can be generated by (i) mixing a gas releasing agent such as $\mathrm{H}_{2} \mathrm{O}_{2}$ or zinc powder in the pasteur cement mortar, or (ii) introducing a large volume of bubbles in mortar. Often different foaming methods, composition of mixture, and curing process will produce individual bubbles with different sizes and distributions, which further affects performance of the FC.
The pore characteristic is an important factor that controls the compressive strength, thermal conductivity, and permeability of the FC. These pores are composed of the interlayer pores/spaces, gel pores, capillary pores, and air void, with pore sizes varying from nanoscale scale to millimeter scale [128]. Some parameters such as volume, size, size distribution, shape, and spacing of pores can be used to characterize these pores [38]. The gel and capillary pores are mainly responsible for the microstructure features [53]. The use of additives and the variation of water cement ratio will affect the pore characteristics. For a given density, the addition of additive reduces the pore size and connectivity so as to obtain the higher strength. The introduction of mineral admixture such as slag or fly ash in FC results in a reduction on the pore size distribution and total porosity [164]. Batool et al. [165] studied the distribution features of pore size in cement-based FC. The results showed that narrower the pore distribution, the greater the conductivity and the smaller the density. The addition of superplasticizer in combination of other additives in foam concrete can further benefit improvement of the pore structure [106].

Researchers found that the pores may be influenced by water cement ratio owing to the changes in the rheological properties and the ability to resist collapse from the foams. It is observed that the pores were small, irregular-shaped, and highly connected at water cement ratios below 0.8 . These pores were determined to be rounded, expansive, and with wider pore size distribution for water cement ratios over 0.8 , because the ability to limit the growth of air bubbles decreased at high water cement ratios [166]. It is reported that reduction of water cement ratio or the addition of fillers often brings difficulties in generating an arranged pore area [53]. Lower water content helps FC to capture the smaller pore size as well as the increased mass density and compressive strength [53]. Pore distribution is one of the important microscopic parameters affecting the strength of foam concrete. In general, foam concrete with narrower bubble distribution will have the higher strength [118].

A review by Zhang et al. [26] summarizes the effects of foaming method on pore properties like size, volume, and shape, as shown in Table 5. It is observed that pore sizes in FC produced by mechanical foaming are smaller than those made by chemical foaming. The connectivity of pores depends on the density of the mixture, not on the foaming method. If the density reaches a level that allows the adhesive to separate individual bubbles, the pores tend to be closed. Otherwise, the FC will be dominated by the opening pore structures.

Hilal et al. [106] used scanning electron microscope (SEM) to characterize pore size and shape parameters, and then studied effects of different additives on strength performance. The investigation demonstrated that addition of additives notably enhanced microstructure and pore structure of FC slurry compared with conventional mixture. Though the additives increase the number of pores, higher strength was obtained due to the reduction of pore size and connectivity, which prevents pores from merging and producing a narrow distribution (see Figure 2). It is confirmed that FC strength not only depends on pore structure 
TABLE 5: Pore features achieved by different foaming methods [26].

\begin{tabular}{lcccc}
\hline Foaming method & $\begin{array}{c}\text { Diameter of } \\
\text { pores }(\mathrm{mm})\end{array}$ & $\begin{array}{c}\text { Volume of } \\
\text { air voids }\end{array}$ & Shape & Density $\left(\mathrm{kg} / \mathrm{m}^{3}\right)$ \\
\hline $\begin{array}{l}\text { Chemical foaming: gas release } \\
\begin{array}{l}\text { Mechanical foaming: High shear mixing or } \\
\text { prefoaming }\end{array}\end{array}$ & $0.5-3.0$ & $15-65 \%$ & $\begin{array}{c}\text { Spherical } \\
\text { Less spherical, with shape } \\
\text { factor 1.2-1.4 }\end{array}$ & Typical AAC: 300-800 \\
\hline
\end{tabular}

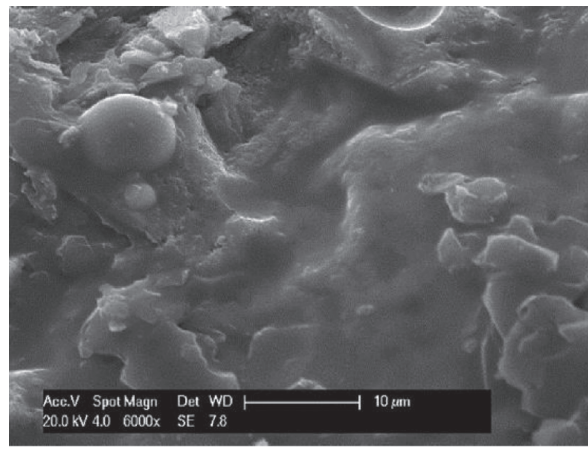

(a)

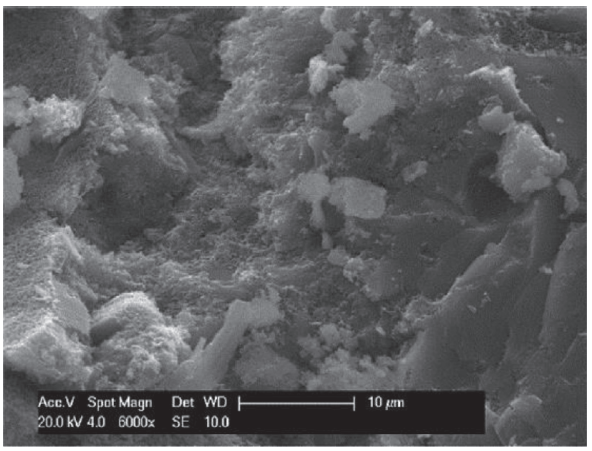

(b)

FIGURE 2: Effect of additives on cement paste microstructure, (a) with additive (more homogeneous) and (b) without additive [106].

enhancement, but also microstructure improvement of the cement paste.

Though many globally sourced literatures on FC have been documented, it is worth noting that research concerning performance enhancement from FC micromechanism should not be neglected, whereas microstructure signifies its various performance behaviors. The macroscopic aspect such as concrete type, filler, additive, foaming agent, and water cement ratio have been widely studied. However, there are very limited literatures on FC microstructure, so this may be a direction for future efforts to improve FC performance.

2.4. Stability. Stability is a major concern in FC. The stability of FC can be defined as a mixture with small, uniform, closed pore structure after hardening and no bleeding and segregation [167]. The stability of the experimental mixture can be evaluated by comparing (i) the calculated and actual quantities required to achieve a plastic density within $50 \mathrm{~kg} / \mathrm{m}^{3}$ of the design value and (ii) the calculated and actual water cement ratio [38]. The stable foam concrete mix depends on many factors viz., density, foaming agent, water to cement ratio, admixture, aggregate, and admixture.

2.4.1. Influence of Density. The stability characteristics of FC were studied by Jones et al. [168], and they found that concretes with a density of less than $500 \mathrm{~kg} / \mathrm{m}^{3}$ are more likely to be unstable. Also, replacement part Portland cement by compatible calcium sulphoaluminate (CSA) cement can produce stable low density mixture. Another study by Jones and McCarthy [138] showed that the instability of FC seems to almost inevitable at a very low density (less than $300 \mathrm{~kg} / \mathrm{m}^{3}$ ).

2.4.2. Influence of Foaming Agent. Lower concentration of foaming agent exerts a positive effect on the stability of FC
[169]. The study by Ghorbani et al. [170] comparatively analyzed the effects of magnetized water on the stability of the synthetic-based and protein-based foaming agents. The results showed that magnetic water presents a positive effect on the stability of synthetic foam, but has an adverse effect on the stability of protein foam. Siva et al. [171] developed a green foaming agent from the natural soap fruit. It could be used as a substitute of synthetic foaming agent, which meets the existing ASTM foaming agent standard. The mixture with high foam content tends to be unstable after pouring, which hinders the development and use of low density FC. Experimental studies showed that severe instability was observed in some high foam content mixtures [172]. The instability could be easily found in the mixture sample when the foam content is over $0.61 \mathrm{~m}^{3}$, showing an increase in instability with the increase of foam content. The results in experiments by Adams et al. [173] confirmed that the foaming agent with $5 \mathrm{wt} . \%$ binder can stabilize the FC at a density of less than $200 \mathrm{~kg} / \mathrm{m}^{3}$. Meanwhile, the pore structure of protein foam concrete is more uniform than that of tenside-based foam concrete. Sun et al. [44] studied the stability and workability of FC prepared with synthetic surfactants, animal glue/blood based surfactants and plant surfactants. They stated that, as a stable nanoparticle foam, synthetic surfactants foam shows the higher stability and air strength than those observed in the other two foams, which is advantageous to improve the performance of FC.

2.4.3. Influence of Mix Ratio. The results of the study by Ghorbani et al. [100] indicated that magnetized water can benefit the stability of FC. For the same mix proportions, the FC specimens with magnetized water show the higher stability than the control samples prepared with regular tap water because of the higher hydration degree. It is reported that the consistency of the base mixture added to foam 
exhibits a notable influence on the stability of the mixture. The spread flow of $45 \%$ in workability value is recommended to produce FC mix in good stability. The water to solid ratio required for producing stable mixtures increases with the addition of fly ash [168]. The adhesion force between particles and bubbles in the base mixture will enhance the stiffness of the mixture. The air foams may affect the stability of the mixture during mixing process, but this could be prevented by employing the higher water-solid ratio [167]. The volume instabilities of cement paste could suffer from the large water binder ratio [103]. Researchers proposed different methods for evaluating the stability of FC mix: (i) density of fresh foamed concrete was compared with its target density, and (ii) the difference between calculated and actual water cement ratio was checked and keep them close to $2 \%[88]$.

2.4.4. Influence of Admixtures and Aggregates. For concrete with a density up to $400 \mathrm{~kg} / \mathrm{m}^{3}, 100 \%$ Portland cement can form a stable mixture. However, for the concrete with a density less than $400 \mathrm{~kg} / \mathrm{m}^{3}$, it is required to replace $5 \%$ to $10 \%$ cement with the compatible calcium aluminate cement so as to obtain stable FC [168]. Cong and Bing [174] pointed out that the addition of silica fume can improve the thermal insulation performance and strength and produce more uniform distribution pores. Though the use of quicklime helps in significantly increasing the density and strength of FC, reduction on the foam stability was observed.

2.4.5. Influence of Additive. The strength improvement and collapse prevention on high-performance FC are both helped by the addition of superplasticizer and a moderate reduction on water cement ratio [166]. In another study, the stability of FC with use of superplasticizer was improved by $43 \%$ when the water binder ratios were set less than 0.3 [168]. Qiao et al. [175] studied the applicability of gemini surfactant as novel air entraining agents for FC. The results showed that gemini surfactants have more stable air entraining capacity and higher surface activity compared to the current standard surfactants used in industry. The gemini surfactants modified with sulfonic groups have the notable stability, air entrainment performance, surface activity, and foaming properties. The use of water reducer to improve the performance of base mix is very effective for improving the stability of FC mixture. The addition of plasticizers increases the workability of the base mix and prevents mixture with foam content of $63-80 \%$ from collapse. The additives in FC produce less stress on the pores, which makes the cement slurry flow more easily between the neighborly pores. This is helpful to lead to a more uniform distribution of cement slurry in pores, reducing the coalesce and increasing the size of pores [172].

Some nano particles, such as nano silica or nanotubes, are always introduced to modify interface between bubbles and cement paste [176]. These nanoparticles gathering at gas-liquid interface helps to reduce the contact area between

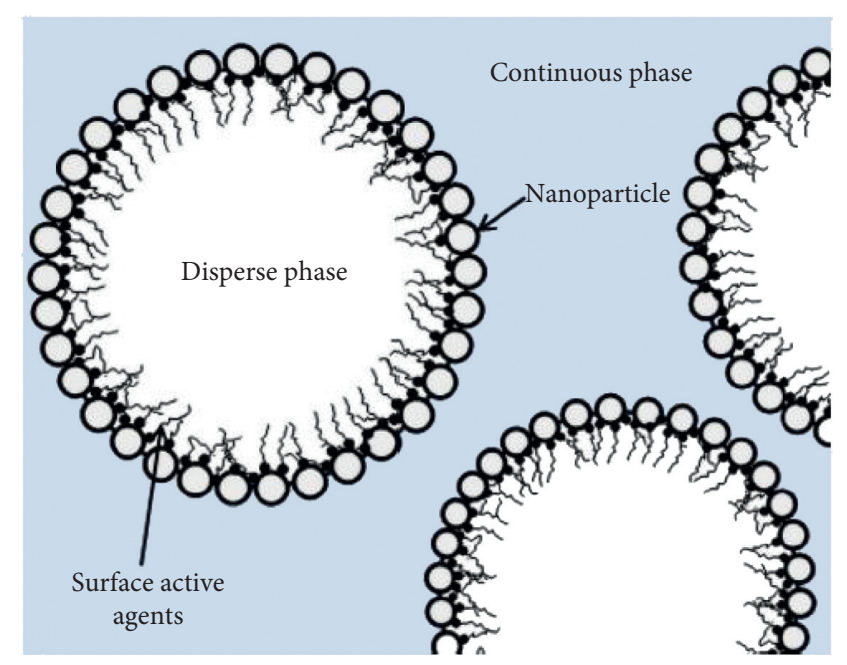

FIGURE 3: Diagrammatic sketch of three-phase-foams after foaming [178].

bubbles and forms a dense particle film to restrain the coalescence and disproportionation of these bubbles. At the same time, a three-dimensional network structure will be formed between the foam surface and the continuous phase, which is advantageous to prolong the drainage time of the liquid membrane [177]. A schematic representation of threephase-foams after foaming reported by Krämer et al. [178] is shown in Figure 3.

Researchers reported that even though nanoparticles are not amphiphilic, most of them are surface active [179]. The hydrophobicity of particles is regarded as a key factor to assess whether the particles could be adsorbed and remained around bubbles. Binks and Horozov [179] modified the silica surface with silanol groups and made it to exhibit different extents of hydrophobicity for the purpose of the investigation on foam stability. The results suggested that the surface contents of $\mathrm{SiOH}$ varying from $30 \%$ to $50 \%$ are advantageous to produce foams with good stability and large foaming capacity. Also, an increase of $\mathrm{pH}$ value or a reduction of $\mathrm{NaCl}$ concentration caused the foams turning from stable three-phase state into unstable two-phase state. Gonzenbach et al. [180] employed short-chain amphiphiles such as carboxylic acids, alkyl gallates, and alkylamines to modify the surfaces of nano silica and nano alumina. In this way, nanoparticles can be adsorbed on the surface of bubbles by chemical bonds so as to produce super stable low-density foams [181].

However, the foams produced by combining nanoparticles with surfactants are not always stable, instead, they sometimes promote the bubble's disappearance. The adsorption of nanoparticles on the bubble surface will accelerate the seepage velocity of the liquid film. The connection of the liquid films and bubbles leads to the burst of the bubbles. Of course, the stability of foam in this situation could be improved by the use of the suitable nanoparticles and surfactants [182]. Tang et al. [183] pointed out that the hydrophilic silica particles combined with sodium dodecyl sulfate (SDS) in FC exhibit a positive foam stabilization effect, whereas the addition of nano silica leads to reduction 
of bubble size. In another study, Alargova et al. [184] reported that the stability of the foams produced by combined use of the SDS and bar polymer particles is lower than that observed in single-particle stabilized foams. In another study, Binks et al. [185] revealed that the stability of bubbles formed by the mixed system of $\mathrm{SiO}_{2}$ and cetyltrimethylammonium bromide (CTAB) was significantly higher than that in the single CTAB system, but the foaming property was slightly weaker. This is because some CTAB was adsorbed onto the surface of the nanoparticles, which increases the hydrophobicity degree of the nano silica. The stability of the foam system was improved, but, at the same time, the foaming capacity was reduced as a result of the reduction in the concentration of the foaming agent in the solution.

2.5. Enhancement. Even though FC has been widely used in nonstructural components, the applications in structural members are still limited due to its strength issue. It is reported that the insufficient strength of FC is mainly because of the uneven distribution of internal pore size. It is easy to lead to stress concentration in small pores under action of the loads, resulting in the destruction of FC. The influence of pore size distribution and pore distribution uniformity on the properties of foam concrete is well known $[115,118]$. Thus, it is essential to minimize the coalescence of bubbles and improve the numbers of small pores and closed pores in foam concrete.

Researchers have made different attempts in order to strengthen FC. Now, the addition of fibers is the most commonly used method to improve the mechanical properties of FC [73, 74]. An investigation by Falliano et al. [92] stated that $0.7 \%$ fibers mixed in FC did not seem to notably improve mechanical strength compared with the reference sample without fibers. It is observed that the flexural strength was significantly improved when increasing the fiber content to $5.0 \%$; however, there is no obvious improvement in the compressive strength was recorded. Especially, the improvement of flexural strength mainly depends on the dry density and is less affected by curing conditions. Dawood and Hamad [75] studied reinforcement effect of glass fibers (GF), polypropylene fiber (PPF), and hybrid fibers (GF + PPF) on the toughness behaviors of highperformance lightweight foam concrete (HPLWFC). The results showed that the use of glass fiber increases the compressive strength, whereas the addition of polypropylene fiber reduces the compressive strength of the HPLWFC. The greatest increment on the compressive strength of the HPLWFC is observed in the experimental species with $0.4 \%$ glass fibers and $0.6 \%$ polypropylene fibers. Experimental results by Hajimohammadi et al. [105] confirmed that use of Xanthan gum (XG) as a thickening agent significantly affects the viscosity of the foam solution and condensates the liquid film around the foams. The drainage and collapse of the prefoaming materials can be greatly reduced with the increase of XG concentration, notably improving the predictability and controllability of the chemical foaming. XG modified samples have smaller and narrower pore size distribution compared to the control sample, which has a positive effect on the thermal conductivity and compressive strength of the specimens.

The control of bubble size has an effect on the performance improvement of FC. Xie et al. [104] pointed out that improving the pore forming method, reducing the size of bubbles and increasing the nanopores in foam concrete have become the key issues for FC research. For the same density, the porosity decreased gradually with the increase of bentonite slurry content, resulting in an increase of wall thickening between pores. The pore size decreased with the increase of bentonite slurry from $0 \%$ to $50 \%$, the average pore size decreased significantly, and the pore size distribution was narrower. The gas in the small bubble enters the large bubble through the liquid film to balance the pressure, so that the bubble is distributed in a large range. The thicker water lubrication film between bubbles restricts the gas exchange of mixture with low precast foam dosage, resulting in uniform pore size.

Jones et al. [168] reported that unstable behavior of bubbles causes the uneven pore size distribution in FC. The combined action from the buoyancy, gravity, slurry pressure, and internal pressure result in instability in bubbles when the bubbles are introduced into the cement paste. The smaller the bubble, the more prominent the instability. This unstable state in bubbles leads to the continuous fusion and growth of bubbles, which makes the bubble size larger. The bubble fusion behaviors are more obvious when a larger amount of foams is used. Also, due to the small amount of slurry, the pressure of the slurry on the bubble becomes smaller and the bubble floats up, which leads to surface settlement and collapse of FC.

Currently, a new way to further improve the performance of FC is introducing the three-phase-foams, which is helpful to weaken the instability by reducing the high interfacial energy and free energy of the system [176]. A study by She et al. [186] made use of the coupling of organic surfactant and nanoparticles to change the gas liquid interface so as to produce super stable foams for FC production. A separation effect between bubbles and fresh cement paste works when the bubbles are added into the cement paste. These bubbles will be balanced under the action of various forces consisting of bubble limiting force $\left(F_{c}\right)$, the gravity $\left(F_{d}\right)$, the internal bubble pressure $\left(P_{i}\right)$, and surface tension $\left(F_{\mathrm{st}}\right)$ as well as bubble buoyancy $\left(F_{b}\right)$ induced by surfactant effect, as shown in Figure 4 .

The instability of the bubbles in normal foams is mainly attributed to the drops of $F_{\text {st }}$ and $F_{c}$; therefore, these bubbles grow easily and float to the upper region of the slurry under action of the $F_{b}$. An undesirable matching between the forces acting on the bubbles and early strength limits the bubble motion, leading to the stratification and uneven density in the foam concrete.

On the contrary, this situation was improved when the bubble surfaces were modified with the addition of nano silica (NS) particles, and the films were enhanced with hydroxypropyl methylcellulose (HPMC). These NS particles increase the surface roughness and the friction drag of the bubbles moving in the cement paste, while the free energy on the bubble surface is absorbed by the NS particles. 


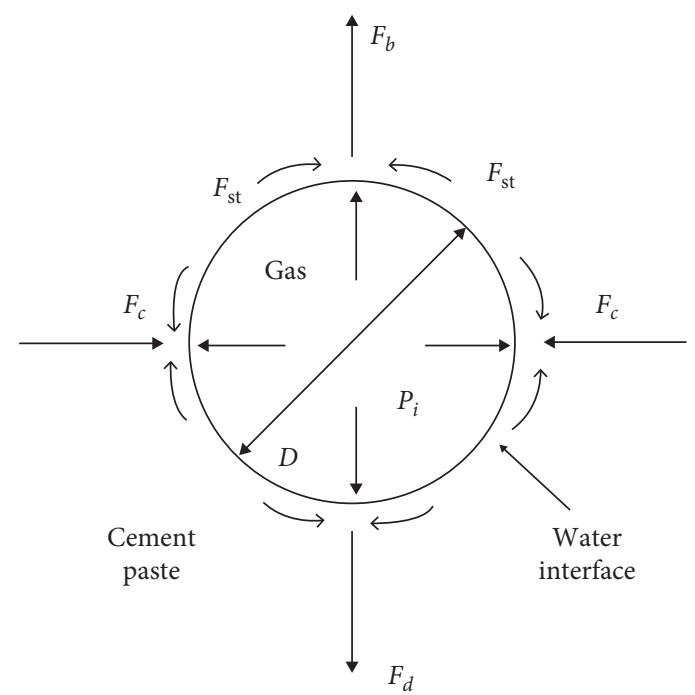

(a)

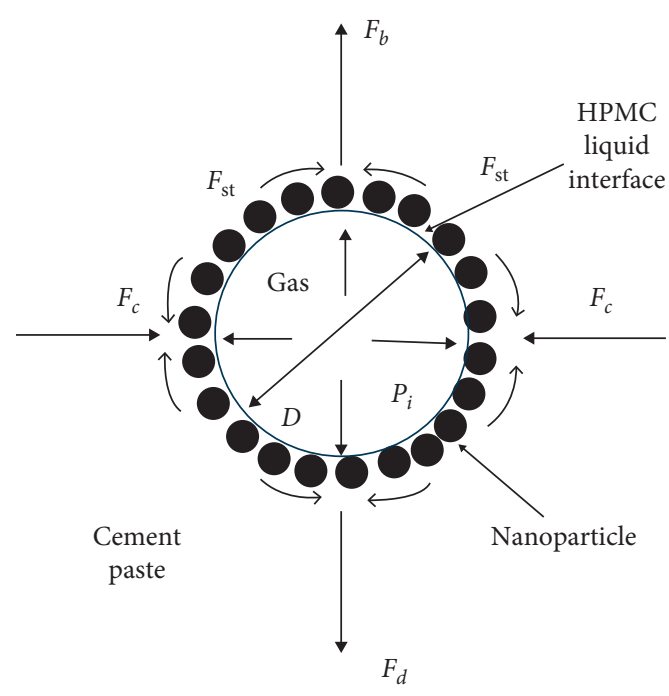

(b)

Figure 4: Forces acting on (a) a normal bubble and (b) a nanoparticle stabilized bubble [186].

In addition, the use of carbon nanotubes as reinforcement components in cement-based materials has attracted a lot of attention. The structure and performance modification in FC can be realized by dispersing the multiwalled carbon nanotubes in foam concrete [187]. The most significant improvements in carbon nanotube-based FC are observed in the mechanical properties $[188,189]$. The addition of carbon nanotubes not only improves the performance of the FC, but also ensures the uniformity of pore size. The dispersion of carbon nanotubes leads to a fine structure of the cement paste which results in dense concretes [188, 189]. A more uniform and compact cement paste is achieved by the effect of calcium hydroxide crystallization. Meanwhile, a higher amount of C-S-H in hydration of concrete is observed because carbon nanotubes play a role in the formation of C-S-H phases [190]. The strengthening is also provided even with a small amount of $0.1 \% \mathrm{w} / \mathrm{w}$ carbon nanotubes related to binder content. It is also reported that the use of carbon nanotubes with low mass content in nonautoclaved concrete reduces its thermal conductivity and improves the mechanical properties [189].

Krämer et al. [176, 178, 191-193] conducted a series of investigations on strengthening of FC by introducing nanoparticles (nano silica, carbon nanotubes) for the purpose of stabilizing the foams. The findings proved that the mechanical properties and bubble structures are both generally improved compared to normal foam concrete. The nanoparticles encapsulating on the foam surface participate in the hydration of the cement, thereby increasing hydration products and enhancing the strength of cellular walls of FC.

A novel method adding pozzolanic active nanomaterials into concrete for reinforcement was put forward recently [193]. The produced foam concretes have higher compressive strength than those observed in industrial FC without needs of further optimization or other enhancement means. These concretes show possibilities to provide comparable properties with industrial lightweight concretes in the future. The foam concretes exhibited a specific formation of hydration products and a shell-like pore structure. Also, the pore size distribution of the FC was under control due to the use of three-phase-foams.

The findings in [176] confirmed that decrease of pore size can be observed by making use of the three-phase-foams, but the wider pore size distribution was observed with adoption of nanotubes. It is also reported that the three-phase-foams combining with other nanomaterials or the obtained approaches can further improve the properties and performance of FC.

\section{Practical Application of FC in Tunnels and Underground Projects}

3.1. Significance and Benefits. The FC has been gradually regarded as a renewed material to address problems faced in tunnels and underground projects. FC performs well with the excellent mechanical properties compared to the ordinary concrete (OC), and some comparisons are presented in Table 6. It is expected to be partially or completely substituted for conventional concrete in underground engineering, providing with economic, social, and environmental benefits.

3.1.1. Excellent Properties. The extensive properties variations of FC are applicable for various situations. Low density (generally from 300 to $1800 \mathrm{~kg} / \mathrm{m}^{3}$ ) helps to reduce dead load without producing lateral load $[26,28]$. A large number of closed small pores containing in FC are responsible for its outstanding fire resistance [206], low thermal conductivity and sound insulation properties $[174,207]$, which are not available in OC. The FC with a density varying between 300 and $1200 \mathrm{~kg} / \mathrm{m}^{3}$ usually has a thermal conductivity value of $0.08-0.3 \mathrm{~W} / \mathrm{mK}[36,208]$. As a result of light weight and low modulus of elasticity, the FC-reinforced structures exhibit considerable aseismic capability by effectively absorbing and 
TABLE 6: Tabulation presents properties comparison between OC and FC [36, 107, 131, 167, 194-205].

\begin{tabular}{|c|c|c|c|c|c|c|c|c|c|}
\hline \multirow[b]{3}{*}{ Type } & \multicolumn{9}{|c|}{ Properties } \\
\hline & \multicolumn{3}{|c|}{ Physical } & \multicolumn{4}{|c|}{ Mechanical } & \multicolumn{2}{|c|}{ Functional } \\
\hline & $\begin{array}{c}\text { Dry } \\
\text { density } \\
\left(\mathrm{kg} / \mathrm{m}^{3}\right)\end{array}$ & $\begin{array}{c}\text { Drying } \\
\text { shrinkage } \\
\quad(\%)\end{array}$ & $\begin{array}{l}\text { Porosity } \\
\text { (\%) }\end{array}$ & $\begin{array}{l}\text { Modulus } \\
\text { of } \\
\text { elasticity } \\
(\mathrm{GPa})\end{array}$ & $\begin{array}{l}\text { Compressive strength } \\
\qquad(\mathrm{MPa})\end{array}$ & $\begin{array}{l}\text { Tensile } \\
\text { strength } \\
(\mathrm{MPa})\end{array}$ & $\begin{array}{c}\text { Flexural } \\
\text { strength } \\
(\mathrm{MPa})\end{array}$ & $\begin{array}{c}\text { Thermal } \\
\text { conductivity } \\
(\mathrm{W} / \mathrm{m} \mathrm{K})\end{array}$ & $\begin{array}{c}\text { Fluidity } \\
(\mathrm{mm})\end{array}$ \\
\hline OC & $2000-2800$ & $0.05-0.1$ & - & $25-38$ & $15-80$ & $0.9-2.5$ & $2.0-9.0$ & ca. 2.5 & ca.190 \\
\hline $\mathrm{FC}$ & $300-1800$ & $0.15-0.35$ & $0-84$ & $0.1-1.0$ & $0.6-43.0$ & $0.05-0.55$ & $0.03-0.9$ & $0.05-0.3$ & $>180$ \\
\hline
\end{tabular}

diffusing shock energy when subjected to the seismic loading. The properties promote the application of FC in tunnel, and underground engineering can be revealed from (1) low self-weight, (2) free flowing and self-leveling, (3) load spreading, (4) insulation capacity, (5) reliable quality control, and (6) freeze and thaw resistance.

3.1.2. Environment Friendly. It is desirable to utilize recycled waste such as fly ash and recycled glass in FC production so as to protect the environment pollution [209]. The main raw materials required for FC are cement and foaming agents. The majority of the foaming agents are nearly neutral surfactants with considerable biodegradability, in which benzene and formaldehyde are usually not contained. Therefore, soil, water, and air are faced with little adverse impacts [210-212], whereas FC can minimize disruption to natural environment during construction phase.

3.1.3. Cost and Time Saving. It could be an economically viable solution, particularly in large-volume applications. Excellent fluidity and self-leveling mean less requirement for energy consumption and manpower moving by using pipes for pumping [213]. On the premise of ensuring FC strength, a large number of industrial wastes can be used as fillers [214]. Therefore, lower investment for FC application is usually attributable to tailored mix design, rapid equipment installation, and cost decrease in maintenance.

3.1.4. Repaid Construction. Pumping FC can be realized by equipping with foam mixer, power pump, and conveying pipeline in a workload of $200-300 \mathrm{~m}^{3} / \mathrm{d}$ within the theoretical vertical height and horizontal distance of $200 \mathrm{~m}$ and $600 \mathrm{~m}$, respectively [215]. A considerable pumping capacity is usually not required as a result of the high fluidity of FC, while mass production and placement are always based on a continuous operation so as to notably improve work efficiency. Also, only limited deliveries for raw materials are needed because the foam acts as the largest volume contributor in FC.

\subsection{Novel Application in Tunnel Engineering}

3.2.1. Thermal Material. In the present years, thermal measures for cold-region tunnels mainly include electric heat tracing, thermal insulation door, and antifreeze thermal insulation layer (i.e., thermal insulating materials laid on liner structure) [216-218]. However, the electric heat tracing needs a lot of energy resources to ensure thermal efficiency, which slightly deviates from the increasingly demanding requests from the perspective of energy saving of constructions. The thermal insulation doors are not suitable for tunnels with large traffic volume, resulting in sizable heat loss owing to incessant opening and closing [219, 220]. Hence, using FC as liner structure and insulation material is helpful to simplify construction process and reduce material costs.

A case study using FC as insulation material in a tunnel in the Tibet, the Alpine Region of China, was reported by Yuan [221], where frozen period with the minimum temperature of $-27.7^{\circ} \mathrm{C}$ lasts eight months every year. Table 7 presents the optimum mix proportion of FC used in the study. The temperature in the measured positions without insulation layer varies significantly compared to location that with insulation layer. The results indicated that temperature change and the minimum temperature in these two locations are $4.5^{\circ} \mathrm{C}, 2^{\circ} \mathrm{C}$ and $1^{\circ} \mathrm{C}, 3^{\circ} \mathrm{C}$, respectively. The findings regarding impacts of freeze-thaw cycles on $\mathrm{FC}$ performance $[44,222]$ will be helpful to further improve and optimize the durability of FC used as insulation materials.

3.2.2. Aseismic Layer. The aseismic layer is generally placed between rock and tunnel liner in order to transfer some of rock mass pressure during construction period so as to avoid liner damage when it is subjected to earthquake action [223-225]. The considerable load-bearing and deformation capacities promote it to be an ideal aseismic material in tunnel engineering. As shown in Table 8, Zhao et al. [226] developed a new aseismic FC material and then applied it in Gonggala tunnel of China. The numerical analysis results showed that this new FC-based material significantly reduced stress and plastic zones in tunnel liner. Meanwhile, an investigation conducted by Huang et al. [227] revealed that using FC as aseismic material is superior to rubber through the durability tests.

3.2.3. Structure Member. Creep deformation in tunnels especially for deep ones will continue after completion of secondary liner [228-231], which easily causes structure damage or failure. Simple increase in secondary liner thickness cannot completely control the creep deformation in rock mass. FC-based members embedded between primary support and secondary liner can notably bear deformation pressure, thereby the high compressibility and 
TABLE 7: Optimum proportion for tunnel antifreeze layer (percentage content) [221].

\begin{tabular}{lccccccccc}
\hline Material & $\begin{array}{c}\text { Fly } \\
\text { ash }\end{array}$ & Perlite & Foam & $\begin{array}{c}\text { Polypropylene } \\
\text { fiber }\end{array}$ & Water & $\begin{array}{c}\text { Water- } \\
\text { proofing } \\
\text { additive }\end{array}$ & $\begin{array}{c}\text { Antifreeze } \\
\text { additive }\end{array}$ & $\begin{array}{c}\text { Water } \\
\text { reducer }\end{array}$ & $\begin{array}{c}\text { Coagulation } \\
\text { accelerator }\end{array}$ \\
\hline Ratio & 30 & 18 & 150 & 0.2 & 40 & 0.3 & 2 & 1 & 4 \\
\hline
\end{tabular}

TABLE 8: Tabulation shows mix proportion of FC used for aseismic isolation layer (unit: $\mathrm{kg} / \mathrm{m}^{3}$ ) [226].

Material Cement Foam Perlite Water Water-proofing additive Antifreeze additive Water reducer Coagulation accelerator Fibre

\begin{tabular}{llllllllll}
\hline Ratio & 600 & 0.8 & 108 & 250 & 5 & 13 & 6.5 & 30 & 1
\end{tabular}

ductility of FC can help to eliminate overall damage or failure. The FC with compressive strength of $0.4-0.7 \mathrm{MPa}$, porosity of $68 \%$, and density of $800 \mathrm{~kg} / \mathrm{m}^{3}$ [232] was adopted in liner system of Tiefengshan No. 2 tunnel to resist gypsumsalt-induced swelling pressure. Since successful implementation in September 2005, the tunnel has been running well, and no damages have arisen.

Wang et al. [233] studied long-term performance of FCbased liner member with a comparison to common largespan soft rock tunnel, the findings showed that after creep for 100 years, vault settlement and horizontal convergence reduced by $61 \%$ and $45 \%$, respectively, while plastic zone in secondary liner was obviously decreased. Wu et al. [234] developed a special yielding support system combined with a new type of FC. This newly developed system was embedded between primary support and secondary liner. The results confirmed that the plastic zone and deformations at the roof and the sides of the secondary liner were significantly reduced as a result of cushion effect, compared to stiff support system.

3.2.4. Backfill and Reinforcement. Table 9 summarizes practical applications of FC used as selective filling material in road tunnels. Specifically, the filling cases mainly include space or cavity fill, open-cut and auxiliary tunnel backfill, bulk fill such as disused tunnel backfill, collapse treatment, etc. And some typical applications are described as follows.

Kontoe [240] reported a backfill case in the Bolu highway twin tunnel repair in Turkey (Figure 5(a)). The tunnel suffered extensive damages during the 1999 Duzce earthquake, and a large amount of FC was temporarily backfilled to stabilize tunnel face during reconstruction activities. The excellent priorities compared to OC give rise to FC application in tunnel collapse treatment. The controllable density and strength as well as good liquidity can fill and then saturate collapsed cavity entirely, thus consolidating fractured body. Figures 5(b) and 5(c) present photos of using FC to reinforce a $20 \mathrm{~m}$ long and $9.6 \mathrm{~m}$ deep collapse body in Shima tunnel, where rock mass was broken and cut obliquely [241]. The subsequent feedbacks from construction site verified the effectiveness of this treatment material.

3.2.5. Dead Load Reduction. Figure 6 illustrates FC application for load reduction while raising ground to a required level that commonly used in metro system. Recently, FC production in Europe, North America, Japan, Korea, China, and Southeast Asia has been the matured technologies.
Other forms for the usages of FC include selective fill and reinforcement for safe construction.

\subsection{Novel Application in Underground Engineering}

3.3.1. Underground Coal Mine Roadway. The FC applications in coal mines are mainly summarized from three aspects: backfilling materials, support system, and water/ harmful gas blocking, which are presented as below:

(1) Backfill Material. As early as 1992, the United States Bureau of Mines had released the programmer of using FC at a density of $720 \mathrm{~kg} / \mathrm{m}^{3}$ to backfill abandoned mines, and the target used for field construction was No. 22 mine in Logan County, West Virginia [242]. And the world's largest single use of FC in mine by far is the stabilization work of Combe Down Stone Mines near Bath of the UK, which eventually used about $400,000 \mathrm{~m}^{3} \mathrm{FC}$ at density and strength of $650 \mathrm{~kg} / \mathrm{m}^{3}$ and $1 \mathrm{MPa}$, respectively (Figure 7) [243].

(2) Support System. Tan et al. [244] put forward a composite support system containing FC damping layer in view of the large deformation in soft rock roadway of coal mine. The results showed that shrinkage of U-shaped steel significantly decreased as the FC absorbs the most of the generated deformation (Figure 8).

(3) Water/gas Blocking. The airtight walls in coal mines are considered to be an effective method to prevent residual coal from spontaneous combustion caused by air leakage. In a study by Wen et al. [245], a new type FC was developed for yielding a wall to control potential air leakage. The $28 \mathrm{~d}$ compressive strength of the FC wall reached $5 \mathrm{MPa}$, in which no remaining fissures were observed; therefore, it effectively suppressed air leakage to the gob (Figure 9).

3.3.2. Public Pipelines and Facilities. Practically, utilizing FC materials for municipal pipelines backfill helps to control postconstruction settlement caused by poor compaction. In Japan, municipal pipelines such as gas pipelines are always filled with FC so as to prevent external damage, especially in areas where earthquakes occur frequently [246].

FC has been expected to use in hydraulic tunnels to resist damages during earthquakes struck. Dowding and Rozen [247] confirmed a series of seismic damage events on hydraulic tunnels in USA by statistical analysis on dozens of 
TABLE 9: Application examples of selective fill with FC.

\begin{tabular}{|c|c|c|c|c|c|}
\hline Reference & Tunnel name & Country & Year & Application & Brief descriptions \\
\hline [235] & $\begin{array}{l}\text { Kent Thameside } \\
\text { tunnels }\end{array}$ & UK & 2010 & Reclamation & $\begin{array}{l}\text { The } 50 \mathrm{~m} \text { deep tunnel extends about } 90 \mathrm{~m} \text {, and FC with density of } \\
400 \mathrm{~kg} / \mathrm{m}^{3} \text { and compressive strength of } 0.5 \mathrm{MPa} \text { was backfilled. }\end{array}$ \\
\hline [236] & Dakota Project & USA & 2000 & $\begin{array}{l}\text { Reinforcement } \\
\text { backfill }\end{array}$ & $\begin{array}{l}\text { The original granular backfill above the tunnel resulted in foundation } \\
\text { foot settlement and finally caused structure deformation. The original } \\
\text { filling was removed and replaced by } 500 \mathrm{~kg} / \mathrm{m}^{3} \text { FC. }\end{array}$ \\
\hline [237] & Farnworth & UK & 2015 & $\begin{array}{l}\text { Auxiliary } \\
\text { construction }\end{array}$ & $\begin{array}{c}\text { The } 7800 \mathrm{~m}^{3} \mathrm{FC} \text { of } 1100 \mathrm{~kg} / \mathrm{m}^{3} \text { and } 1 \mathrm{MPa} \text { was used to backfill the one } \\
\text { of a } 300 \mathrm{~m} \text { long double-hole tunnel so as to accept the Tunnelling } \\
\text { Boring Machine (TBM). }\end{array}$ \\
\hline [235] & Thackley & UK & 2013 & $\begin{array}{l}\text { Structural } \\
\text { reinforcement }\end{array}$ & $\begin{array}{l}\text { As more distortion was recorded, with the crown being forced } \\
\text { upwards into a void. A total } 2540 \mathrm{~m}^{3} \mathrm{FC} \text { with } 1120-1130 \mathrm{~kg} / \mathrm{m}^{3} \text { and } \\
1 \mathrm{MPa} \text { was required for fillers. }\end{array}$ \\
\hline [238] & Huashiya & China & 2015 & Cavity filling & $\begin{array}{c}\text { Cavities and cracks appeared in secondary liner of tunnel, and then } \\
\text { these defects were filled by FC grouting. }\end{array}$ \\
\hline [235] & $\begin{array}{l}\text { Gerrards Cross } \\
\text { project }\end{array}$ & UK & 2009 & Load reduction & $\begin{array}{l}\text { To reduce dead load, pile walls were installed on both sides of the } \\
\text { tunnel, and } 26,000 \mathrm{~m}^{3} \mathrm{FC} \text { with } 375 \mathrm{~kg} / \mathrm{m}^{3} \text { was used to form horizontal } \\
\text { ground at the top of vault. }\end{array}$ \\
\hline [239] & Wulaofeng & China & 2009 & $\begin{array}{l}\text { Seepage water } \\
\text { treatment }\end{array}$ & $\begin{array}{l}\text { The seepage of tunnel side wall was serious, and some locations were } \\
\text { even gushing, so FC was used as waterproof material. }\end{array}$ \\
\hline
\end{tabular}

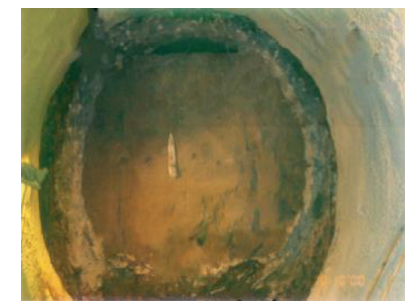

(a)

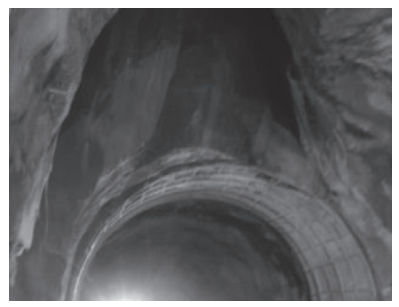

(b)

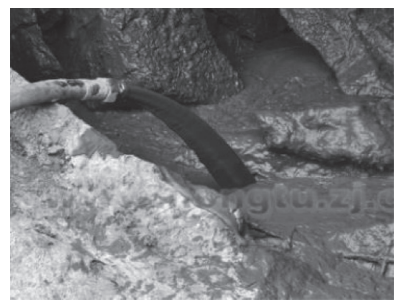

(c)

Figure 5: (a) Bolu highway twin tunnel [240], (b) collapse, and (c) treatment with pumped FC in Shima tunnel [241].

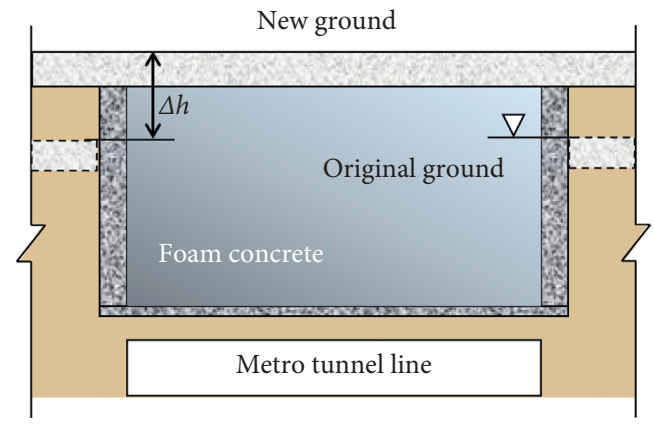

(a)

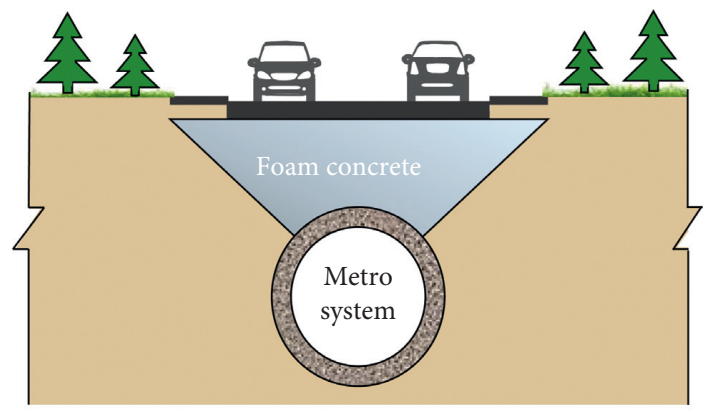

(b)

FIGURE 6: FC application in metro system.

case tunnels. The similar seismic hazards were also be documented in Japan during the 1995 Osaka-Kobe earthquake $\left(M_{\mathrm{s}}=7.2\right)$, in which water supply pipelines and sewage drainage systems in Hanshin and adjacent areas were severely damaged. The water supply systems in Kobe were even completely destroyed [248, 249]. Currently, many contributions have been made to use FC as antiseismic material in hydraulic tunnels. The Port Mann Water Tunnel Project, located in Vancouver, Canada, was constructed with a total $6000 \mathrm{~m}^{3} \mathrm{FC}$ to meet a seismic backfill requirement for 100-year reliability [250].

\section{Thoughts and Future Work for Popularization of FC}

4.1. Emerging Direction for Performance Enhancement of FC. Though a lot of research has been carried out focusing on macroscopic properties of FC, such as thermal conductivity, mechanical properties, water absorption, etc., the studies on drying shrinkage, bubble size control, stability, and pore structure characterization are still insufficient.

Ghorbani et al. [110] used scanning electron microscope (SEM) to study FC microstructure. The results showed that 


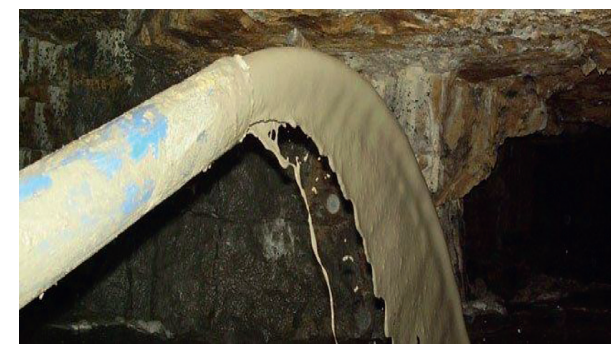

Figure 7: Combe down stone mines (source: http://www. foamedconcrete.co.uk).

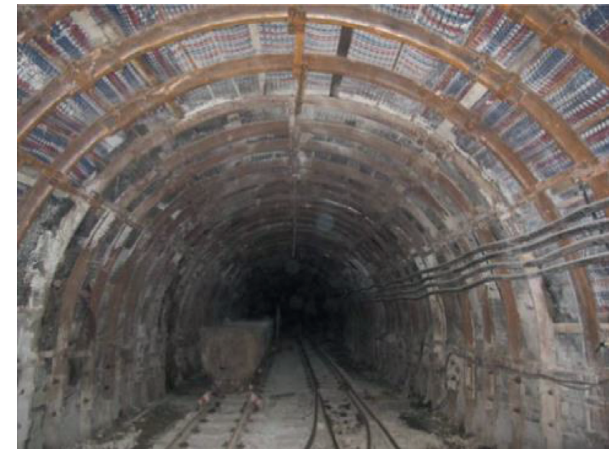

FIgURE 8: A composite supporting system containing FC [244].

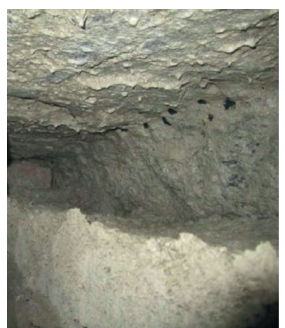

(a)

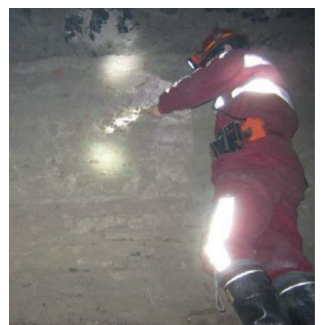

(b)
FIGURE 9: Filling effect of FC wall after (a) 24 hours and (b) 28 days [245].

the FC microstructure was notably improved by using magnetized water instead of conventional tap water. The FC structure with magnetized water has a lower porosity and is denser than that with conventional tap water. Using magnetized water in FC increases its stability and compressive and tensile strengths as well as reduces the water absorption.

The FC microstructure filled with silica fume was studied by Reisi et al. [251]. The SEM and X-ray diffraction tests showed that the reaction between silica fume and free calcium hydroxide in hydrated cement generates the hydrated calcium silicate. Its hardness and durability are higher than calcium hydroxide so as to reduce the risk of sulfate attack in silica fume FC. Consequently, the hydrated calcium silicate produced homogeneous FC with better solid and pore distribution, which leads to a higher compressive strength compared to FC without silica fume.

The X-ray microCT imaging results reported by Chung et al. [252] confirmed that the shape and size of pores and local density of the solids have remarkable impacts on performance and damage mode of FC, which has profound guiding significance for high-performance FC production. In addition, Zhang and Wang [128] confirmed that pore size notably affected the compressive strength of glass-fiberreinforced FC, especially at a high porosity. The pore shape maintains relatively constant as a result of the function of foam content and density variation, which does not bring about much effect on mechanical properties of FC.

There are relatively few studies on FC microstructure such as shrinkage mechanism, shrinkage prediction, strength improvement, etc. To be sure, all of the abovementioned studies are helpful to deeply understand durability issues; therefore, linking the microstructure and macro-performance of FC in order to better enhance its performance should be deeply investigated.

4.2. Technical Limitation. Dramatically, the mix proportions of FC have always been the technical challenge and one of the research hotspots. So far, there are no clearly defined methods to determine the mix proportion despite some experimental-based and error-based methods can be used. Recently, Tan et al. [8] proposed an equation for mix proportion determination:

$$
\begin{aligned}
\rho_{d} & =S_{a} M_{c}, \\
V_{2} & =K\left(1-V_{1}\right)=K\left[1-\left(\frac{M_{c}}{\rho_{c}}+\frac{M_{w}}{\rho_{w}}\right)\right], \\
M_{y} & =V_{2} \rho_{f}, \\
M_{p} & =\frac{M_{y}}{\alpha+1},
\end{aligned}
$$

where $\rho_{d}$ is the dry density of the designed FC $\left(\mathrm{kg} / \mathrm{m}^{3}\right), S_{a}$ is the empirical coefficient, $M_{c}$ is the mass of cement $\left(\mathrm{kg} / \mathrm{m}^{3}\right)$, $V_{1}$ and $V_{2}$ are the volume of cement paste and foam, respectively, $\rho_{c}$ and $\rho_{w}$ are the densities of cement and water, respectively, $M_{c}$ and $M_{w}$ are the cement and water, respectively, $K$ is the coefficient, $M_{y}$ and $\rho_{f}$ are the mass and density of foam, respectively, $M_{p}$ is the mass of foaming agent, and $\alpha$ is the dilution ratio.

Practically, water quality, cement, lime, and other aggregates worldwide are characterized by unique features and the technical level for fiber preparation varies greatly. The optimum mix proportion of FC will also be affected by regional environments [253]. Hence, it is necessary to determine the best mixing proportion under different regional tests, avoiding using existing mix proportion schemes directly. This challenge may be one of the important factors restricting worldwide applications of FC in tunnel engineering [254-256].

Develop cheaper foaming agents and generators are also urgent tasks to promote practicality and wider application of FC. The compatibility between foaming agents and various admixtures should be studied to strengthening FC. Meanwhile, to reduce water demand and shrinkage, in-deep study on compatibility of chemical admixtures is required. The 
difficulties encountered in FC production such as mixing, transportation, and pumping also need to be solved, whereas they exhibit significant impacts on freshness and hardening properties of FC [64].

4.3. Government Support. Regarding as a kind of green construction material, FC accords with increasing demands of sustainable perspective of construction for countries worldwide. The booming development of infrastructures has increased the demands for various new environmental protection materials, in which the FC plays a key role. With the government support, whether the policy or economic aspect, the more scientific research outputs from universities, research institutes, and enterprises will be obtained, which is conducive to enhance establishment and reform of the relevant industrial systems, thereby alleviating consumer concerns.

4.4. Other Considerations. Lack of the complete production data and construction experience makes it difficult to form the complete construction systems. Therefore, establishing the reliable design and construction procedures for FC usage is helpful to overcome the construction difficulties. Moreover, relevant specifications, codes, and standards should be implemented timely so as to standardize the design and construction processes of FC.

\section{Conclusions}

Based on the review conducted, it was observed that most of the studies on FC have been conducted to the evaluation of its properties rather than on the foam features, which has impacts on the strength and enhancement of the foam material. According to the findings provided by researchers, the following conclusions are drawn from extensive literature review:

(1) To enhance FC performance and popularization, the relevant properties were elaborated and some aspects were proposed as constraints for wider application of FC such as drying shrinkage, strength issue, stability, enhancement, and long-term durability.

(2) Foam stability is a significant aspect which significantly affects the strength of FC. Production of the stable FC requires to consider many factors such as the method of preparation of foam, type of foaming agent, the accuracy of the mixture, type of surfactants and additives used, usage of nano particles and mix design, etc.

(3) Very few studies on durability of FC are available. Durability properties of FC mainly influenced by the ratio of connected pore to total pore. The FC with uniformly distributed closed circular air pores exerts good thermal and mechanical properties.

(4) Current research mainly focuses on the microscopical characterization of FC and the impacts of the several factors on the physical, mechanical, and functional performance. However, very limited literatures have put emphasis on systemic microstructure characterization of FC.

(5) The use of three-phase-foams instead of wet foams based on surfactants or proteins and water for improving the performance of FC has been renewed interests because the incorporation of three-phasefoams in cement paste is advantageous to stabilize the pores and control the pore size distribution.

\section{Conflicts of Interest}

The authors declare no conflicts of interest.

\section{Acknowledgments}

The financial support from the National Natural Science Foundation of China (No. 51678363), Shenzhen Science and Technology Project (No. JCYJ20150525092941052), Underground Engineering (Tongji University) (No. KLETJGEB0905), Project on Social Development of Shaanxi Provincial Science and Technology Department (No. 2018SF-382, No. 2018SF-378), and Fundamental Research Funds for the Central University, CHD (Nos. 300102219711, 300102219716 and 300102219723) is sincerely acknowledged.

\section{References}

[1] E. K. K. Nambiar and K. Ramamurthy, "Influence of filler type on the properties of foam concrete," Cement and Concrete Composites, vol. 28, no. 5, pp. 475-480, 2006.

[2] Y. Wang, S. H. Zhang, D. T. Niu, L. Su, and D. M. Luo, "Strength and chloride ion distribution brought by aggregate of basalt fiber reinforced coral aggregate concrete," Construction and Building Materials, vol. 234, Article ID 117390, 2020.

[3] J. Narayanan and K. Ramamurthy, "Identification of setaccelerator for enhancing the productivity of foamed concrete block manufacture," Construction and Building Materials, vol. 37, pp. 144-152, 2012.

[4] M. R. Jones, K. Ozlutas, and L. Zheng, "High-volume, ultralow-density fly ash foamed concrete," Magazine of Concrete Research, vol. 69, no. 22, pp. 1146-1156, 2017.

[5] Ş. Kilincarslan, M. Davraz, and M. Akça, "The effect of pumice as aggregate on the mechanical and thermal properties of foam concrete," Arabian Journal of Geosciences, vol. 11, no. 11, Article ID 289, 2018.

[6] D. T. Niu, L. Zhang, F. Qiang, B. Wen, and D. M. Luo, "Critical conditions and life prediction of reinforcement corrosion in coral aggregate concrete," Construction and Building Materials, vol. 238, Article ID 117685, 2020.

[7] D. Falliano, D. D. Domenico, G. Ricciardi, and E. Gugliandolo, "Experimental investigation on the compressive strength of foamed concrete: effect of curing conditions, cement type, foaming agent and dry density," Construction and Building Materials, vol. 165, pp. 735-749, 2018.

[8] X. J. Tan, W. Z. Chen, J. H. Wang et al., "Influence of high temperature on the residual physical and mechanical properties of foamed concrete," Construction and Building Materials, vol. 135, pp. 203-211, 2017.

[9] T. Liu, Y. J. Zhong, Z. L. Han, and W. Xu, "Deformation characteristics and countermeasures for a tunnel in difficult geological environment in NW China," Advances in Civil Engineering, vol. 2020, Article ID 1694821, 16 pages, 2020. 
[10] Y. Wei, W. Guo, and Q. Zhang, "A model for predicting evaporation from fresh concrete surface during the plastic stage," Drying Technology, vol. 37, no. 11, pp. 12-23, 2019.

[11] M. A. Othuman and Y. C. Wang, "Elevated-temperature thermal properties of lightweight foamed concrete," Construction and Building Materials, vol. 25, pp. 705-716, 2011.

[12] A. A. Sayadi, J. V. Tapia, T. R. Neitzert, and G. C. Clifton, "Effects of expanded polystyrene (EPS) particles on fire resistance, thermal conductivity and compressive strength of foamed concrete," Construction and Building Materials, vol. 11, pp. 716-724, 2016.

[13] S. Tada, "Material design of aerated concrete-an optimum performance design," Materials and Structures, vol. 19, no. 1, pp. 21-26, 1986.

[14] H. K. Kim, J. H. Jeon, and H. K. Lee, "Workability, and mechanical, acoustic and thermal properties of lightweight aggregate concrete with a high volume of entrained air," Construction and Building Materials, vol. 29, pp. 193-200, 2012.

[15] R. C. Valore, "Cellular concrete part 2 physical properties," ACI Journal Proceedings, vol. 50, no. 6, pp. 817-836, 1954.

[16] Z. M. Huang, T. S. Zhang, and Z. Y. Wen, "Proportioning and characterization of Portland cement-based ultra-lightweight foam concretes," Construction and Building Materials, vol. 79, pp. 390-396, 2015.

[17] M. Decký, M. Drusa, K. Zgútová, M. Blaško, M. Hájek, and W. Scherfel, "Foam concrete as new material in road constructions," Procedia Engineering, vol. 161, pp. 428-433, 2016.

[18] M. Kadela and M. Kozłowski, "Foamed concrete layer as substructure of industrial concrete floor," Procedia Engineering, vol. 161, pp. 468-476, 2016.

[19] Z. H. Zhang, J. L. Provis, A. Reid, and H. Wang, "Mechanical, thermal insulation, thermal resistance and acoustic absorption properties of geopolymer foam concrete," Cement and Concrete Composites, vol. 62, pp. 97-105, 2015.

[20] A. S. Tarasov, E. P. Kearsley, A. S. Kolomatskiy, and H. F. Mostert, "Heat evolution due to cement hydration in foamed concrete," Magazine of Concrete Research, vol. 62, no. 12, pp. 895-906, 2010.

[21] Y. Wei, J. Huang, and S. Liang, "Measurement and modeling concrete creep considering relative humidity effect," $\mathrm{Me}$ chanics of Time-dependent Materials, vol. 24, no. 1, pp. 1-17, 2020.

[22] Y. Y. Li, Y. M. Sun, J. L. Qiu, T. Liu, L. Yang, and H. D. She, "Moisture absorption characteristics and thermal insulation performance of thermal insulation materials for cold region tunnels," Construction and Building Materials, vol. 237, Article ID 117765, 2020.

[23] X. Z. Li, C. Z. Qi, and P. C. Zhang, "A micro-macro confined compressive fatigue creep failure model in brittle solids," International Journal of Fatigue, vol. 130, p. 14, 2020.

[24] Z. Q. Zhang and J. L. Yang, "Improving safety of runway overrun through foamed concrete aircraft arresting system: an experimental study," International Journal of Crashworthiness, vol. 20, no. 5, pp. 448-463, 2015.

[25] P. Favaretto, G. E. N. Hidalgo, C. H. Sampaio, R. D. A. Silva, and R. T. Lermen, "Characterization and use of construction and demolition waste from south of Brazil in the production of foamed concrete blocks," Applied Sciences, vol. 7, no. 10, pp. 1-15, 2017.

[26] Z. H. Zhang, J. L. Provis, A. Reid, and H. Wang, "Geopolymer foam concrete: an emerging material for sustainable construction," Construction and Building Materials, vol. 56, pp. 113-127, 2014.

[27] P. Prabha, G. S. Palani, N. Lakshmanan, and R. Senthil, "Behaviour of steel-foam concrete composite panel under inplane lateral load," Journal of Constructional Steel Research, vol. 139, pp. 437-448, 2017.

[28] J. Hulimka, R. Krzywoń, and A. Jędrzejewska, "Laboratory tests of foamed concrete slabs reinforced with composite grid," Procedia Engineering, vol. 193, pp. 337-344, 2017.

[29] J. L. Qiu, Y. Q. Lu, J. X. Lai, C. X. Guo, and K. Wang, "Failure behavior investigation of loess metro tunnel under localhigh-pressure water environment," Engineering Failure Analysis, vol. 112, no. 4, 2020.

[30] J. Z. Pei, B. C. Zhou, and L. Lyu, "e-Road: the largest energy supply of the future?” Applied Energy, vol. 241, pp. 174-183, 2019.

[31] L. X. Wang, E. L. Ma, H. Li et al., "Tunnelling induced settlement and treament techniques for a Loess Metro in Xi'an," Advances in Civil Engineering, vol. 2020, Article ID 1854813, 16 pages, 2020.

[32] X. G. Yu, G. H. Xing, and Z. Q. Chang, "Flexural behavior of reinforced concrete beams strengthened with near-surface mounted 7075 aluminum alloys bars," Journal of Building Engineering, vol. 28, 2020.

[33] T. Zhang, D. T. Niu, and C. Rong, "GFRP-confined coral aggregate concrete cylinders: The experimental and theoretical analysis," Construction and Building Materials, vol. 218, pp. 206-213, 2019.

[34] Y. C. Zheng, Y. H. Zhang, L. X. Wang, K. Wang, and T. Liu, "Mechanical reinforcement mechanism of steel fiber reinforced concrete and its application in tunnels," Advances in Civil Engineering, vol. 2020, Article ID 3479475, 16 pages, 2020.

[35] K. H. Yang, K. H. Lee, J. K. Song, and M. H. Gong, "Properties and sustainability of alkali-activated slag foamed concrete," Journal of Cleaner Production, vol. 68, pp. 226233, 2014.

[36] S. Wei, Y. Q. Chen, Y. S. Zhang, and M. R. Jones, "Characterization and simulation of microstructure and thermal properties of foamed concrete," Construction and Building Materials, vol. 47, pp. 1278-1291, 2013.

[37] Y. H. M. Amran, N. Farzadnia, and A. A. A. Abang, "Properties and applications of foamed concrete: a review," Construction and Building Materials, vol. 101, pp. 990-1005, 2015.

[38] K. Ramamurthy, K. K. K. Nambiar, and G. I. S. Ranjani, "A classification of studies on properties of foam concrete," Cement and Concrete Composites, vol. 31, no. 6, pp. 388-396, 2009.

[39] Y. Zheng, J. Xiong, T. Liu, X. Yue, and J. Qiu, "Performance of a deep excavation in Lanzhou strong permeable sandy gravel strata," Arabian Journal of Geosciences, vol. 13, no. 16, p. 12, 2020.

[40] H. Sun, Q. P. Wang, P. Zhang, Y. J. Zhong, and X. B. Yue, "Spatiotemporal characteristics of tunnel traffic accidents in China from 2001 to present," Advances in Civil Engineering, vol. 2019, Article ID 4536414, 12 pages, 2019.

[41] L. X. Wang, C. H. Li, J. L. Qiu, K. Wang, and T. Liu, "Treatment and Effect of loess metro tunnel under surrounding pressure and water immersion environment," Geofluids, vol. 2020, Article ID 7868157, 15 pages, 2020.

[42] X. J. Tan, W. Z. Chen, H. Y. Liu, and A. H. C. Chan, "Stressstrain characteristics of foamed concrete subjected to large deformation under uniaxial and triaxial compressive 
loading," Journal of Materials in Civil Engineering, vol. 30, no. 6, pp. 1-10, 2018.

[43] P. J. Tikalsky, J. Pospisil, and W. MacDonald, "A method for assessment of the freeze-thaw resistance of preformed foam cellular concrete," Cement and Concrete Research, vol. 34, pp. 889-893, 2004.

[44] C. Sun, Y. Zhu, J. Guo, Y. M. Zhang, and G. X. Sun, "Effects of foaming agent type on the workability, drying shrinkage, frost resistance and pore distribution of foamed concrete," Construction and Building Materials, vol. 186, pp. 833-839, 2018.

[45] S. Mindess, Developments in the Formulation and Reinforcement of Concrete, Woodhead publishing limited, Cambridge, UK, 2008.

[46] H. L. Zhao, H. T. Yu, Y. Yuan, and H. B. Zhu, "Blast mitigation effect of the foamed cement-base sacrificial cladding for tunnel structures," Construction and Building Materials, vol. 94, pp. 710-718, 2015.

[47] H. Choi and S. Ma, "An optimal lightweight foamed mortar mix suitable for tunnel drainage carried out using the composite lining method," Tunnelling and Underground Space Technology, vol. 47, pp. 93-105, 2015.

[48] K. C. Brady, G. R. A. Watts, and M. R. Jones, Application Guide AG39: Specification for Foamed Concrete, Highway Agency and Transport Research Laboratory, Workingham, Berks, UK, 2001.

[49] S. Van Dijk, "Foam concrete," Concrete, vol. 25, pp. 49-54, 1991.

[50] C. Karakurt, H. Kurama, and İ. B. Topçu, "Utilization of natural zeolite in aerated concrete production," Cement and Concrete Composites, vol. 32, no. 1, pp. 1-8, 2010.

[51] V. Kočí, J. Maděra, and R. Černý, “Computer aided design of interior thermal insulation system suitable for autoclaved aerated concrete structures," Applied Thermal Engineering, vol. 58, no. 1-2, pp. 165-172, 2013.

[52] H. S. Shang and Y. P. Song, "Triaxial compressive strength of air-entrained concrete after freeze-thaw cycles," Cold Regions Science and Technology, vol. 90-91, pp. 33-37, 2013.

[53] A. Just and B. Middendorf, "Microstructure of high-strength foam concrete," Materials Characterization, vol. 60 , no. 7 , pp. 741-748, 2009.

[54] R. C. Valore, "Cellular concrete part 1 composition and methods of production," ACI Journal Proceedings, vol. 50, pp. 773-796, 1954.

[55] Sach and H. Seifert, "Foamed concrete technology: possibilities for thermal insulation at high temperatures," Ceramic Forum International, vol. 76, pp. 23-30, Göller, 1999.

[56] G. Rudnai, Lightweight Concretes, Akademikiado, Budapest, Hungary, 1963.

[57] A. Short and W. Kinniburgh, Lightweight Concrete, Asia Publishing House, Delhi, India, 1963.

[58] K. Marcin and K. Marta, "Mechanical characterization of lightweight foamed concrete," Advances in Materials Science and Engineering, vol. 2018, pp. 1-8, 2018.

[59] M. R. Jones and A. Mccarthy, "Preliminary views on the potential of foamed concrete as a structural material," Magazine of Concrete Research, vol. 57, no. 1, pp. 21-31, 2005.

[60] M. A. O. Mydin and Y. C. Wang, "Structural performance of lightweight steel-foamed concrete-steel composite walling system under compression," Thin-Walled Structures, vol. 49, no. 1, pp. 66-76, 2011.

[61] E. K. K. Nambiar and K. Ramamurthy, "Models relating mixture composition to the density and strength of foam concrete using response surface methodology," Cement and Concrete Composites, vol. 28, no. 9, pp. 752-760, 2006.

[62] ACI Committee 523, "Guide for cellular concrete above 50 pcf and for aggregate concretes above 50 pcf with compressive strengths less than 2500 psi," ACI Journal Proceeding, vol. 72, no. 2, 1975.

[63] E. P. Kearsley and P. J. Wainwright, "The effect of high fly ash content on the compressive strength of foamed concrete," Cement and Concrete Research, vol. 31, pp. 105-112, 2001.

[64] S. S. Sahu, I. S. R. Gandhi, and S. Khwairakpam, "State-ofthe-art review on the characteristics of surfactants and foam from foam concrete perspective," Journal of the Institution of Engineers (India): Series A, vol. 99, no. 2, pp. 391-405, 2018.

[65] C. Pickford and S. Crompton, "Foamed concrete in bridge construction," Concrete, vol. 30, pp. 14-15, 1996.

[66] M. I. Norlia, R. C. Amat, N. L. Rahim, and S. Sallehuddin, "Performance of lightweight foamed concrete with replacement of concrete sludge aggregate as coarse aggregate," Advanced Materials Research, vol. 689, pp. 265-268, 2013.

[67] T. H. Wee, S. B. Daneti, and T. Tamilselvan, "Effect of w/c ratio on air-void system of foamed concrete and their influence on mechanical properties," Magazine of Concrete Research, vol. 63, no. 8, pp. 583-595, 2011.

[68] M. B. Youssef, F. Lavergne, K. Sab, K. Miled, and J. Neji, "Upscaling the elastic stiffness of foam concrete as a threephase composite material," Cement and Concrete Research, vol. 110, pp. 13-23, 2018.

[69] A. Hajimohammadi, T. Ngo, and A. Kashani, "Sustainable one-part geopolymer foams with glass fines versus sand as aggregates," Construction and Building Materials, vol. 171, pp. 223-231, 2018.

[70] A. Kashani, T. D. Ngo, P. Hemachandra, and A. Hajimohammadi, "Effects of surface treatments of recycled tyre crumb on cement-rubber bonding in concrete composite foam," Construction and Building Materials, vol. 171, pp. 467-473, 2018.

[71] S. K. Agarwal, I. Masood, and S. K. Malhotra, "Compatibility of superplasticizers with different cements," Construction and Building Materials, vol. 14, pp. 253-259, 2000.

[72] A. Zingg, F. Winnefeld, L. Holzer et al., "Interaction of polycarboxylate-based superplasticizers with cements containing different C3A amounts," Cement and Concrete Composites, vol. 31, no. 3, pp. 153-162, 2009.

[73] C. Bing, W. Zhen, and L. Ning, "Experimental research on properties of high-strength foamed concrete," Journal of Materials in Civil Engineering, vol. 24, no. 1, pp. 113-118, 2011.

[74] O. Kayali, M. N. Haque, and B. Zhu, "Some characteristics of high strength fiber reinforced lightweight aggregate concrete," Cement and Concrete Composites, vol. 25, no. 2, pp. 207-213, 2003.

[75] E. T. Dawood and A. J. Hamad, "Toughness behaviour of high-performance lightweight foamed concrete reinforced with hybrid fibres," Structural Concrete, vol. 16, no. 4, pp. 496-507, 2015.

[76] M. S. Mahzabin, L. J. Hock, M. S. Hossain, and L. S. Kang, "The influence of addition of treated kenaf fibre in the production and properties of fibre reinforced foamed composite," Construction and Building Materials, vol. 178, pp. 518-528, 2018.

[77] H. Awang, M. H. Ahmad, and M. Almulali, "Influence of kenaf and polypropylene fibres on mechanical and durability properties of fibre reinforced lightweight foamed concrete," 
Journal of Engineering Science and Technology, vol. 10, no. 4, pp. 496-508, 2015.

[78] H. Awang and M. H. Ahmad, "Durability properties of foamed concrete with fiber inclusion," International Journal of Civil, Structural, Construction and Architectural Engineering, vol. 8, pp. 273-276, 2014.

[79] M. A. O. Mydin, N. A. Rozlan, and S. Ganesan, "Experimental study on the mechanical properties of coconut fibre reinforced lightweight foamed concrete," Journal of Materials and Environmental Science, vol. 6, no. 2, pp. 407-411, 2015.

[80] V. Fedorov and A. Mestnikov, "Influence of cellulose fibers on structure and properties of fiber reinforced foam concrete," in Proceedings of the 4th International Young Researchers Conference on Youth, Science, Solutions: Ideas and Prospects, YSSIP 2017, vol. 143, December 2018.

[81] W. Abbas, E. Dawood, and Y. Mohammad, "Properties of foamed concrete reinforced with hybrid fibres," in Proceedings of the 3rd International Conference on Buildings, Construction and Environmental Engineering, BCEE3 2017, vol. 162, October 2018.

[82] R. J. Pugh, "Foaming, foam films, antifoaming and defoaming," Advances in Colloid and Interface Science, vol. 64, pp. 67-142, 1996.

[83] I. T. Koudriashoff, "Manufacture of reinforced foam concrete roof slabs," ACI Journal Proceedings, vol. 46, no. 9, pp. 37-68, 1949.

[84] F. Zulkarnain and M. Ramli, "Durability of performance foamed concrete mix design with silica fume for housing development," Journal of Materials Science and Engineering, vol. 5, pp. 518-527, 2011.

[85] P. Chindaprasirt and U. Rattanasak, "Shrinkage behavior of structural foam lightweight concrete containing glycol compounds and fly ash," Materials and Design, vol. 32, no. 2, pp. 723-727, 2011.

[86] M. R. Jones, M. J. McCarthy, and A. McCarthy, "Moving fly ash utilisation in concrete forward: A UK perspective,", in Proceedings of the 2003 International Ash Utilization Symposium, Center for Applied Energy Research, University of Kentucky, Lexington, KY, USA, 2003.

[87] P. E. Regan and A. R. Arasteh, "Lightweight aggregate foamed concrete," Structural Engineer, vol. 68, no. 9, pp. 167-73, 1990.

[88] M. R. Jones and A. Mccarthy, "Heat of hydration in foamed concrete: effect of mix constituents and plastic density," Cement and Concrete Research, vol. 36, no. 6, pp. 1032-1041, 2006.

[89] K. T. Wan, H. G. Zhu, T. Y. P. Yuen et al., "Development of low drying shrinkage foamed concrete and hygro-mechanical finite element model for prefabricated building fasçade applications," Construction and Building Materials, vol. 165, pp. 939-957, 2018.

[90] E. K. K. Nambiar and K. Ramamurthy, "Shrinkage behavior of foam concrete," Journal of Materials in Civil Engineering, vol. 21, no. 11, pp. 631-636, 2009.

[91] H. Weigler and S. Karl, "Structural lightweight aggregate concrete with reduced density-lightweight aggregate foamed concrete," International Journal of Cement Composites and Lightweight Concrete, vol. 2, no. 2, pp. 101-104, 1980.

[92] D. Falliano, D. D. Domenico, G. Ricciardi, and E. Gugliandolo, "Compressive and flexural strength of fiberreinforced foamed concrete: Effect of fiber content, curing conditions and dry density," Construction and Building Materials, vol. 198, pp. 479-493, 2019.
[93] C. L. Hwang and V. A. Tran, "Engineering and durability properties of self-consolidating concrete incorporating foamed lightweight aggregate," Journal of Materials in Civil Engineering, vol. 28, no. 9, Article ID 04016075, 2016.

[94] W. She, Y. Du, G. T. Zhao, P. Feng, Y. S. Zhang, and X. Y. Cao, "Influence of coarse fly ash on the performance of foam concrete and its application in high-speed railway roadbeds," Construction and Building Materials, vol. 170, pp. 153-166, 2018.

[95] V. N. Tarasenko, "Impact of foamed matrix components on foamed concrete properties," IOP Conference Series Materials Science and Engineering, vol. 327, Article ID 032054, 2018.

[96] W. H. Zhao, Q. Su, W. B. Wang, L. L. Niu, and T. Liu, "Experimental study on the effect of water on the properties of cast in situ foamed concrete," Advances in Materials Science and Engineering, vol. 2018, Article ID 7130465, 2018.

[97] N. Makul and G. Sua-Iam, "Characteristics and utilization of sugarcane filter cake waste in the production of lightweight foamed concrete," Journal of Cleaner Production, vol. 126, pp. 118-133, 2016.

[98] A. I. Kudyakov and A. B. Steshenko, "Shrinkage deformation of cement foam concrete," IOP Conference Series-Materials Science and Engineering, vol. 71, Article ID 012019, 2015.

[99] X. M. Chen, Y. Yan, Y. Z. Liu, and Z. H. Hu, "Utilization of circulating fluidized bed fly ash for the preparation of foam concrete," Construction and Building Materials, vol. 54, pp. 137-146, 2014.

[100] S. Ghorbani, S. Ghorbani, Z. Tao, J. D. Brito, and M. Tavakkolizadeh, "Effect of magnetized water on foam stability and compressive strength of foam concrete," Construction and Building Materials, vol. 197, pp. 280-290, 2019.

[101] D. M. A. Huiskes, A. Keulen, Q. L. Yu, and H. J. H. Brouwers, "Design and performance evaluation of ultra-lightweight geopolymer concrete," Materials and Design, vol. 89, pp. 516-526, 2016.

[102] Z. M. Jaini, S. N. Mokhatar, A. S. M. Yusof, S. Zulkiply, and M. H. A. Rahman, "Effect of pelletized coconut fibre on the compressive strength of foamed concrete," in Proceedings of the 3rd International Conference on Civil and Environmental Engineering for Sustainability, vol. 47, Article ID 01013, Malacca, Malaysia, 2015.

[103] Z. W. Liu, K. Zhao, C. Hu, and Y. F. Tang, "Effect of watercement ratio on pore structure and strength of foam concrete," Advances in Materials Science and Engineering, vol. 2016, Article ID 9520294, 2016.

[104] Y. Xie, J. Li, Z. Y. Lu, J. Jiang, and Y. H. Niu, "Effects of bentonite slurry on air-void structure and properties of foamed concrete," Construction and Building Materials, vol. 179, pp. 207-219, 2018.

[105] A. Hajimohammadi, T. Ngo, and P. Mendis, "Enhancing the strength of pre-made foams for foam concrete applications," Cement and Concrete Composites, vol. 87, pp. 164-171, 2018.

[106] A. A. Hilal, N. H. Thom, and A. R. Dawson, "On void structure and strength of foamed concrete made without/ with additives," Construction and Building Materials, vol. 85, pp. 157-164, 2015.

[107] S. K. Lim, C. S. Tan, X. Zhao, and T. C. Ling, "Strength and toughness of lightweight foamed concrete with different sand grading," KSCE Journal of Civil Engineering, vol. 19, no. 7, pp. 2191-2197, 2015.

[108] R. Gowri, K. B. Anand, R. Gowri, and K. B. Anand, "Utilization of fly ash and ultrafine GGBS for higher strength foam concrete," in Proceedings of the International Conference on 
Advances in Materials and Manufacturing Applications, IOP Conference Series: Materials Science and Engineering, vol. 310, Article ID 012070, Melbourne, Australia, September 2018.

[109] T. J. Chandni and K. B. Anand, "Utilization of recycled waste as filler in foam concrete," Journal of Building Engineering, vol. 19, pp. 154-160, 2018.

[110] S. K. Lim, C. S. Tan, B. Li, T. C. Ling, M. U. Hossain, and C. S. Poon, "Utilizing high volumes quarry wastes in the production of lightweight foamed concrete," Construction and Building Materials, vol. 151, pp. 441-448, 2017.

[111] S. B. Park, E. S. Yoon, and B. I. Lee, "Effects of processing and materials variations on mechanical properties of lightweight cement composites," Cement and Concrete Research, vol. 29, pp. 193-200, 1999.

[112] X. D. Chen, S. X. Wu, and J. K. Zhou, "Influence of porosity on compressive and tensile strength of cement mortar," Construction and Building Materials, vol. 40, pp. 869-874, 2013.

[113] C. Lian, Y. Zhuge, and S. Beecham, "The relationship between porosity and strength for porous concrete," Construction and Building Materials, vol. 25, pp. 4294-4298, 2011.

[114] E. K. K. Nambiar and K. Ramamurthy, "Models for strength prediction of foam concrete," Materials and Structures, vol. 41, pp. 247-254, 2008.

[115] E. Papa, V. Medri, D. Kpogbemabou et al., "Porosity and insulating properties of silica-fume based foams," Energy and Buildings, vol. 131, pp. 223-232, 2016.

[116] J. Feng, R. F. Zhang, L. L. Gong, Y. Li, W. Cao, and X. D. Cheng, "Development of porous fly ash-based geopolymer with low thermal conductivity," Materials and Design, vol. 65, pp. 529-533, 2015.

[117] F. S. Han, G. Seiffert, Y. Y. Zhao, and B. Gibbs, "Acoustic absorption behaviour of an open-celled aluminium foam," Journal of Physics D: Applied Physics, vol. 36, p. 294, 2003.

[118] E. K. K. Nambiar and K. Ramamurthy, "Air-void characterisation of foam concrete," Cement and Concrete Research, vol. 37, no. 2, pp. 221-230, 2007.

[119] C. T. Tam, T. Y. Lim, R. S. Ravindrarajah, and S. L. Lee, "Relationship between strength and volumetric composition of moist-cured cellular concrete," Magazine of Concrete Research, vol. 39, no. 138, pp. 12-18, 1987.

[120] M. H. Thakrele, "Experimental study on foam concrete," International Journal of Civil, Structural, Environmental and Infrastructure Engineering Research and Development, vol. 4, no. 1, pp. 145-158, 2014.

[121] J. H. Lee, "Influence of concrete strength combined with fiber content in the residual flexural strengths of fiber reinforced concrete," Composite Structures, vol. 168, pp. 216-25, 2017.

[122] M. Nehdi, Y. Djebbar, and A. Khan, "Neural network model for preformed-foam cellular concrete," ACI Materials Journal, vol. 98, no. 5, pp. 402-409, 2001.

[123] A. Baykasoğlu, H. Güllü, H. Çanakçı, and L. Özbakır, "Prediction of compressive and tensile strength of limestone via genetic programming," Expert Systems with Applications, vol. 35, no. 1-2, pp. 111-123, 2008.

[124] T. Nguyen, A. Kashani, T. Ngo, and S. Bordas, "Deep neural network with high-order neuron for the prediction of foamed concrete strength," Computer-Aided Civil and Infrastructure Engineering, vol. 34, pp. 316-332, 2019.

[125] Z. M. Yaseen, R. C. Deo, A. Hilal et al., "Predicting compressive strength of lightweight foamed concrete using extreme learning machine model," Advances in Engineering Software, vol. 115, pp. 112-125, 2018.
[126] ACI Committee 523, Guide for Cast-in-Place Lowdensity Cellular Concrete, Farmington Hills, MI, USA, 2006.

[127] W. H. Zhao, J. J. Huang, Q. Su, and T. Liu, "Models for strength prediction of high-porosity cast-in-situ foamed concrete," Advances in Materials Science and Engineering, vol. 2018, Article ID 3897348, 2018.

[128] Z. H. Zhang and H. Wang, "The pore characteristics of geopolymer foam concrete and their impact on the compressive strength and modulus," Frontiers in Materials, vol. 3, pp. 1-10, 2016.

[129] E. P. Kearsley and P. J. Wainwright, "The effect of porosity on the strength of foamed concrete," Cement and Concrete Research, vol. 32, no. 2, pp. 233-239, 2002.

[130] E. P. Kearsley and P. J. Wainwright, "Ash content for optimum strength of foamed concrete," Cement and Concrete Research, vol. 32, no. 2, pp. 241-246, 2002.

[131] E. P. Kearsley and P. J. Wainwright, "Porosity and permeability of foamed concrete," Cement and Concrete Research, vol. 31, no. 5, pp. 805-812, 2001.

[132] M. Rößler and I. Odler, "Investigations on the relationship between porosity, structure and strength of hydrated Portland cement pastes I effect of porosity," Cement and Concrete Research, vol. 15, no. 2, pp. 320-330, 1985.

[133] G. C. Hoff, "Porosity-strength considerations for cellular concrete," Cement and Concrete Research, vol. 2, no. 1, pp. 91-100, 1972.

[134] L. Cox and S. Van Dijk, "Foam concrete: a different kind of mix," Concrete, vol. 36, pp. 54-55, 2002.

[135] B. K. Nyame, "Permeability of normal and lightweight mortars," Magazine of Concrete Research, vol. 37, no. 130, pp. 44-48, 1985.

[136] A. A. Hilal, N. H. Thom, and A. R. Dawson, "Pore structure and permeation characteristics of foamed concrete," Journal of Advanced Concrete Technology, vol. 12, no. 12, pp. 535$544,2014$.

[137] R. L. Day and B. K. Marsh, "Measurement of porosity in blended cement pastes," Cement and Concrete Research, vol. 18, no. 1, pp. 63-73, 1988.

[138] M. R. Jones and A. McCarthy, "Utilising unprocessed lowlime coal fly ash in foamed concrete," Fuel, vol. 84, no. 11, pp. 1398-1409, 2005.

[139] E. K. K. Nambiar and K. Ramamurthy, "Sorption characteristics of foam concrete," Cement and Concrete Research, vol. 37, no. 9, pp. 1341-1347, 2007.

[140] E. Namsone, G. Šahmenko, and A. Korjakins, "Durability properties of high-performance foamed concrete," Procedia Engineering, vol. 172, pp. 760-767, 2017.

[141] H. S. Shang and Y. P. Song, "Experimental study of strength and deformation of plain concrete under biaxial compression after freezing and thawing cycles," Cement and Concrete Research, vol. 36, no. 10, pp. 1857-1864, 2006.

[142] H. D. Yun, S. W. Kim, Y. O. Lee, and K. Rokugo, “Tensile behavior of synthetic fiber-reinforced strain-hardening cement-based composite (SHCC) after freezing and thawing exposure," Cold Regions Science and Technology, vol. 67, no. 1-2, pp. 49-57, 2011.

[143] S. Tsivilis, G. Batis, E. Chaniotakis, G. Grigoriadis, and D. Theodossis, "Properties and behavior of limestone cement concrete and mortar," Cement and Concrete Research, vol. 30, no. 10, pp. 1679-1683, 2000.

[144] R. Jones, L. Zheng, A. Yerramala, and K. S. Rao, "Use of recycled and secondary aggregates in foamed concretes," Magazine of Concrete Research, vol. 64, no. 6, pp. 513-525, 2012 . 
[145] H. T. Cao, L. Bucea, A. Ray, and S. Yozghatlian, "The effect of cement composition and $\mathrm{pH}$ of environment on sulfate resistance of Portland cements and blended cements," Cement and Concrete Composites, vol. 19, no. 2, pp. 161-171, 1997.

[146] P. Brown, R. D. Hooton, and B. Clark, "Microstructural changes in concretes with sulfate exposure," Cement and Concrete Composites, vol. 26, no. 8, pp. 993-999, 2004.

[147] M. Sahmaran, O. Kasap, K. Duru, and I. O. Yaman, "Effects of mix composition and water-cement ratio on the sulfate resistance of blended cements," Cement and Concrete Composites, vol. 29, no. 3, pp. 159-167, 2007.

[148] G. I. S. Ranjani and K. Ramamurthy, "Behaviour of foam concrete under sulphate environments," Cement and Concrete Composites, vol. 34, no. 7, pp. 825-834, 2012.

[149] P. Chindaprasirt, S. Rukzon, and V. Sirivivatnanon, "Resistance to chloride penetration of blended Portland cement mortar containing palm oil fuel ash, rice husk ash and fly ash," Construction and Building Materials, vol. 22, pp. 932-938, 2008.

[150] M. R. Jones and A. McCarthy, Behaviour and Assessment of Foamed Concrete for Construction Applications, Thomas Telford, London, UK, 2005.

[151] S. Chandra and L. Berntsson, Lightweight Aggregate Concrete, ASTM Special Technical Publication, Philadelphia, PA, USA, 1994.

[152] D. Aldridge and T. Ansell, "Foamed concrete: production and equipment design, properties, applications and potential," in Proceedings of the One Day Seminar on Foamed Concrete: Properties, Applications and Latest Technological Developments, pp. 1-7, Loughborough University, Loughborough, England, UK, 2001.

[153] A. Proshin, V. A. Beregovoi, A. M. Beregovoi, and I. A. Eremkin, Unautoclaved Foam Concrete and its Constructions, Adapted to the Regional Conditions, Thomas Telford, London, UK, 2005.

[154] A. Giannakou and M. R. Jones, Potentials of Foamed Concrete to Enhance the Thermal Performance of Low Rise Dwellings, Thomas Telford, London, UK, 2002.

[155] N. Mohd Zahari, I. Abdul Rahman, A. Zaidi, and A. Mujahid, "Foamed concrete: potential application in thermal insulation,", in Proceedings of the Malaysian Technical Universities Conference on Engineering and Technology (MUCEET), MS Garden, Kuantan, Pahang, Malaysia, 2009.

[156] O. P. Shrivastava, "Lightweight aerated concrete-a review," Indian Concrete Journal, vol. 51, pp. 10-23, 1977.

[157] B. Nagy, S. G. Nehme, and D. Szagri, "Thermal properties and modeling of fiber reinforced concretes," Energy Procedia, vol. 78, pp. 2742-2747, 2015.

[158] H. Awang, A. O. Mydin, and M. H. Ahmad, "Mechanical and durability properties of fiber lightweight foamed concrete," Australian Journal of Basic and Applied Sciences, vol. 7, no. 7, pp. 14-21, 2013.

[159] F. Y. Yang, "Study on influence factors of foam concrete properties," MS thesis, Southwest University of Science and Technology, Mianyang, China, 2009.

[160] T. G. Richard, "Low temperature behaviour of cellular concrete," ACI Journal Proceedings, vol. 74, no. 4, pp. 173178, 1977.

[161] T. G. Richard, J. A. Dobogai, T. D. Gerhardt, and W. C. Young, "Cellular concrete-a potential load-bearing insulation for cryogenic applications," IEEE Transactions on Magnetics, vol. 11, no. 2, pp. 500-503, 1975.
[162] R. Kumar, R. Lakhani, and P. Tomar, "A simple novel mix design method and properties assessment of foamed concretes with limestone slurry waste," Journal of Cleaner Production, vol. 171, pp. 1650-1663, 2018.

[163] G. Sang, Y. Zhu, G. Yang, and H. B. Zhang, "Preparation and characterization of high porosity cement-based foam material," Construction and Building Materials, vol. 91, pp. 133-137, 2015.

[164] N. Gowripalan, J. G. Cabrera, A. R. Cusens, and P. J. Wainwright, "Effect of curing on durability," Concrete International, vol. 12, no. 12, pp. 47-54, 1990.

[165] F. Batool and V. Bindiganavile, "Air-void size distribution of cement based foam and its effect on thermal conductivity," Construction and Building Materials, vol. 149, pp. 17-28, 2017.

[166] J. Jiang, Z. Lu, Y. Niu, J. Li, and Y. Zhang, "Study on the preparation and properties of high-porosity foamed concretes based on ordinary Portland cement," Materials and Design, vol. 92, pp. 949-959, 2016.

[167] E. K. K. Nambiar and K. Ramamurthy, "Fresh state characteristics of foam concrete," Journal of Materials in Civil Engineering, vol. 20, no. 2, pp. 111-117, 2008.

[168] M. R. Jones, K. Ozlutas, and L. Zheng, "Stability and instability of foamed concrete," Magazine of Concrete Research, vol. 68 , no. 11 , pp. 542-549, 2016.

[169] E. Kuzielová, L. Pach, and M. Palou, "Effect of activated foaming agent on the foam concrete properties," Construction and Building Materials, vol. 125, pp. 998-1004, 2016.

[170] S. Ghorbani, S. Sharifi, J. de Brito, S. Ghorbani, M. A. Jalayer, and M. Tavakkolizadeh, "Using statistical analysis and laboratory testing to evaluate the effect of magnetized water on the stability of foaming agents and foam concrete," Construction and Building Materials, vol. 207, pp. 28-40, 2019.

[171] M. Siva, K. Ramamurthy, and R. Dhamodharan, "Development of a green foaming agent and its performance evaluation," Cement and Concrete Composites, vol. 80, pp. 245-257, 2017.

[172] A. Bagheri and S. A. Samea, "Parameters influencing the stability of foamed concrete," Journal of Materials in Civil Engineering, vol. 30, no. 6, Article ID 04018091, 2018.

[173] T. Adams, A. Vollpracht, J. Haufe, L. Hildebrand, and S. Brell-Cokcan, "Ultra-lightweight foamed concrete for an automated facade application," Magazine of Concrete Research, vol. 71, no. 8, pp. 424-436, 2019.

[174] M. Cong and C. Bing, "Properties of a foamed concrete with soil as filler," Construction and Building Materials, vol. 76, pp. 61-69, 2015.

[175] M. Qiao, J. Chen, C. Yu, S. S. Wu, N. X. Gao, and Q. P. Ran, "Gemini surfactants as novel air entraining agents for concrete," Cement and Concrete Research, vol. 100, pp. 4046, 2017.

[176] C. Krämer, M. Schauerte, T. Müller, S. Gebhard, and R. Trettin, "Application of reinforced three-phase-foams in UHPC foam concrete," Construction and Building Materials, vol. 131, pp. 746-757, 2017.

[177] T. S. Horozov, "Foams and foam films stabilised by solid particles," Current Opinion in Colloid and Interface Science, vol. 13, no. 3, pp. 134-140, 2008.

[178] C. Krämer, T. L. Kowald, and R. H. F. Trettin, "Pozzolanic hardened three-phase-foams," Cement and Concrete Composites, vol. 62, pp. 44-51, 2015. 
[179] B. P. Binks and T. S. Horozov, "Aqueous foams stabilized solely by silica nanoparticles," Angewandte Chemie International Edition, vol. 44, no. 24, pp. 3722-3725, 2005.

[180] U. T. Gonzenbach, A. R. Studart, E. Tervoort, and L. J. Gauckler, "Stabilization of foams with inorganic colloidal particles," Langmuir the ACS Journal of Surfaces and Colloids, vol. 22, no. 26, Article ID 10983, 2006.

[181] A. R. Studart, U. T. Gonzenbach, I. Akartuna, E. Tervoort, and L. J. Gauckler, "Materials from foams and emulsions stabilized by colloidal particles," Journal of Materials Chemistry, vol. 17, no. 31, pp. 3283-3289, 2007.

[182] Y. Du, Preparation of Nano-Modified Foam Concrete and its Stability and Enhancement Mechanism, Southeast University, pp. 9-10, Nanjing, China, MS thesis, 2018.

[183] F. Q. Tang, Z. Xiao, J. A. Tang, and L. Jiang, "The effect of $\mathrm{SiO}_{2}$ particles upon stabilization of foam," Journal of Colloid and Interface Science, vol. 131, no. 2, pp. 498-502, 1989.

[184] R. G. Alargova, D. S. Warhadpande, V. N. Paunov, and O. D. Velev, "Foam super stabilization by polymer microrods," Langmuir, vol. 20, no. 24, pp. 10371-10374, 2004.

[185] B. P. Binks, M. Kirkland, and J. A. Rodrigues, "Origin of stabilisation of aqueous foams in nanoparticle-surfactant mixtures," Soft Matter, vol. 4, no. 12, pp. 2373-2382, 2008.

[186] W. She, Y. Du, C. W. Miao et al., "Application of organicand nanoparticle-modified foams in foamed concrete: reinforcement and stabilization mechanisms," Cement and Concrete Research, vol. 106, pp. 12-22, 2018.

[187] J. Keriene, M. Kligys, A. Laukaitas, G. Yakolev, A. Spokauskas, and M. Aleknevicius, "The influence of multi-walled carbon nanotubes additive on properties of non-autoclaved and autoclaved aerated concretes," Construction and Building Materials, vol. 49, pp. 527-535, 2013.

[188] G. Yakolev, G. Pervushin, I. Maeva et al., "Modification of construction materials with multi-walled carbon nanotubes," Procedia Engineering, vol. 57, pp. 407-413, 2013.

[189] G. Yakolev, J. Keriene, A. Gailius, and I. Girniene, "Cement based foam concrete reinforced by carbon nanotubes," Materials Science, vol. 12, no. 2, pp. 147-151, 2006.

[190] G. Y. Li, P. M. Wang, and X. Zhao, "Mechanical behavior and microstructure of cement composites incorporating surface-treated multi-walled carbon nanotubes," Carbon, vol. 43, no. 6, pp. 1239-1245, 2005.

[191] C. Krämer, O. M. Azubike, and R. H. F. Trettin, "Reinforced and hardened three-phase-foams," Cement and Concrete Composites, vol. 73, pp. 174-184, 2016.

[192] C. Krämer and R. H. F. Trettin, "Investigations of nanostructured three-phase-foams and their application in foam concretes-a summary," Advanced Materials Letters, vol. 8, no. 11, pp. 1072-1079, 2017.

[193] C. Krämer, M. Schauerte, T. L. Kowald, and R. H. F. Trettin, "Three-phase-foams for foam concrete application," Materials Characterization, vol. 102, pp. 173-179, 2015.

[194] N. Narayanan and K. Ramamurthy, "Structure and properties of aerated concrete: a review," Cement and Concrete Composites, vol. 22, no. 5, pp. 321-329, 2000.

[195] H. Al-Khaiat and M. N. Haque, "Effect of initial curing on early strength and physical properties of a lightweight concrete," Cement and Concrete Research, vol. 28, no. 6, pp. 859-866, 1998.

[196] O. Kayali, M. N. Haque, and B. Zhu, "Drying shrinkage of fibre-reinforced lightweight aggregate concrete containing fly ash," Cement and Concrete Research, vol. 29, no. 11, pp. 1835-1840, 1999.
[197] M. Gesoglu, T. Özturan, and E. Güneyisi, "Shrinkage cracking of lightweight concrete made with cold-bonded fly ash aggregates," Cement and Concrete Research, vol. 34, no. 7, pp. 1121-1130, 2004.

[198] D. D. Domenico, "RC members strengthened with externally bonded FRP plates: a FE-based limit analysis approach," Composites Part B: Engineering, vol. 71, pp. 159-174, 2015.

[199] W. Piasta, J. Góra, and W. Budzyński, "Stress-strain relationships and modulus of elasticity of rocks and of ordinary and high-performance concretes," Construction and Building Materials, vol. 153, pp. 728-739, 2017.

[200] J. Xie and J. B. Yan, "Experimental studies and analysis on compressive strength of normal-weight concrete at low temperatures," Structural Concrete, vol. 19, pp. 1235-1244, 2017.

[201] D. Q. Li, Z. L. Li, C. C. Lv, G. H. Zhang, and Y. M. Yin, “A predictive model of the effective tensile and compressive strengths of concrete considering porosity and pore size," Construction and Building Materials, vol. 170, pp. 520-526, 2018.

[202] K. Ding, "Technology research on flexible fining defects of tunnel structure," MS thesis, School of Civil Engineering, Shandong University, Jinan, China, 2018.

[203] C. Rudolph and J. Valore, "Cellular concretes part 2 physical properties," ACI Journal Proceedings, vol. 50, pp. 817-836, 1954.

[204] A. O. Richard and M. Ramli, "Experimental production of sustainable lightweight foamed concrete," British Journal of Applied Science and Technology, vol. 3, no. 4, pp. 994-1005, 2013.

[205] A. F. Roslan, H. Awang, and M. Mydin, "Effects of various additives on drying shrinkage, compressive and flexural strength of lightweight foamed concrete (LFC)," Advanced Materials Research, vol. 626, pp. 594-604, 2013.

[206] M. A. O. Mydin and Y. C. Wang, "Mechanical properties of foamed concrete exposed to high temperatures," Construction and Building Materials, vol. 26, pp. 638-654, 2012.

[207] C. Ma and B. Chen, "Experimental study on the preparation and properties of a novel foamed concrete based on magnesium phosphate cement," Construction and Building Materials, vol. 137, pp. 160-168, 2017.

[208] F. Gouny, F. Fouchal, P. Maillard, and S. Rossignol, "A geopolymer mortar for wood and earth structures," Construction and Building Materials, vol. 32, pp. 188-195, 2012.

[209] L. Z. Liu, S. Miramini, and A. Hajimohammadi, "Characterising fundamental properties of foam concrete with a non-destructive technique," Nondestructive Testing and Evaluation, vol. 34, no. 1, pp. 54-69, 2019.

[210] K. K. B. Siram and R. K. Arjun, "Concrete + Green = Foam Concrete," International Journal of Civil Engineering and Technology, vol. 4, pp. 179-184, 2013.

[211] A. S. Moon and V. Varghese, "Sustainable construction with foam concrete as a green building material," International Journal of Modern Trends in Engineering and Research, vol. 2, no. 2, pp. 13-16, 2014.

[212] A. S. Moon, V. Varghese, and S. S. Waghmare, "Foam concrete as a green building material," International Journal of Research in Engineering and Technology, vol. 2, no. 9, pp. 25-32, 2015.

[213] W. She, M. R. Jones, Y. S. Zhang, and X. Shi, "Potential use of foamed mortar (FM) for thermal upgrading of Chinese traditional Hui-style residences," International Journal of Architectural Heritage, vol. 9, no. 7, pp. 775-793, 2015. 
[214] K. Jitchaiyaphum, T. Sinsiri, C. Jaturapitakkul, and P. Chindaprasirt, "Cellular lightweight concrete containing high-calcium fly ash and natural zeolite," International Journal of Minerals, Metallurgy, and Materials, vol. 20, no. 5, pp. 462-471, 2013.

[215] X. Yu, "Research on foaming agent for preparation of light foam concrete," MS thesis, College of Science, Northeastern University, Shenyang, China, 2015.

[216] M. N. Wang, Y. C. Dong, and L. Yi, "Analytical solution for loess tunnel based on the bilinear strength criterion," Soil mechanics and Foundation Engineering, vol. 57, no. 3, pp. 151-163, 2020.

[217] T. Liu, Y. J. Zhong, Z. H. Feng, W. Xu, and F. T. Song, "New construction technology of a shallow tunnel in bouldercobble mixed grounds," Advances in Civil Engineering, vol. 2020, Article ID 5686042, 14 pages, 2020.

[218] J. X. Lai, X. L. Wang, J. L. Qiu et al., "A state-of-the-art review of sustainable energy-based freeze proof technology for coldregion tunnels in China," Renewable and Sustainable Energy Reviews, vol. 82, no. 3, pp. 3554-3569, 2018.

[219] X. L. Weng, Y. F. Sun, B. H. Yan, H. S. Niu, R. A. Lin, and S. Q. Zhou, "Centrifuge testing and numerical modeling of tunnel face stability considering longitudinal slope angle and steady state seepage in soft clay," Tunnelling and Underground Space Technology, vol. 96, pp. 218-229, 2020.

[220] Z. Zhou, Y. Dong, P. Jiang, D. Han, and T. Liu, "Calculation of pile side friction by multiparameter statistical analysis," Advances in Civil Engineering, vol. 2019, Article ID 2638520, 12 pages, 2019.

[221] K. K. Yuan, "High-strength and heat insulation foam concrete: developing and applying in cold region tunnel," Journal of Glaciology and Geocryology, vol. 38, pp. 438-444, 2016.

[222] W. Z. Chen, H. M. Tian, J. Q. Yuan, and J. X. Tan, "Degradation characteristics of foamed concrete with lightweight aggregate and polypropylene fibre under freeze-thaw cycles," Magazine of Concrete Research, vol. 65, no. 12, pp. 720-730, 2013.

[223] Y. Y. Li, S. S. Xu, H. Q. Liu, E. L. Ma, and L. X. Wang, "Displacement and stress characteristics of tunnel foundation in collapsible loess ground reinforced by jet grouting columns," Advances in Civil Engineering, vol. 2018, Article ID 2352174, 2018.

[224] Z. C. Wang, Y. L. Xie, H. Q. Liu, and Z. H. Feng, "Analysis on deformation and structural safety of a novel concrete-filled steel tube support system in loess tunnel," European Journal of Environmental and Civil Engineering, vol. 2018, pp. 1-21, 2019.

[225] S. B. Zhang, S. Y. He, J. L. Qiu, W. Xu, R. Garnes, and L. X. Wang, "Displacement characteristics of a urban tunnel in silty soil by shallow tunnelling method," Advances in Civil Engineering, vol. 2020, Article ID 3975745, 16 pages, 2020.

[226] W. S. Zhao, W. Z. Chen, X. J. Tan, and S. Huang, "Study on foamed concrete used as seismic isolation material for tunnels in rock," Materials Research Innovations, vol. 17, no. 7, pp. 465-472, 2013.

[227] S. Huang, W. Z. Chen, J. P. Yang, X. H. Guo, and C. J. Qiao, "Research on earthquake-induced dynamic responses and aseismic measures for underground engineering," Chinese Journal of Rock Mechanics and Engineering, vol. 28, no. 3, pp. 483-490, 2009.

[228] M. Gasc-Barbier, S. Chanchole, and P. Bérest, "Creep behavior of bure clayey rock," Applied Clay Science, vol. 26, no. 1-4, pp. 449-458, 2004.
[229] M. J. Heap, P. Baud, P. G. Meredith, S. Vinciguerra, A. F. Bell, and I. G. Maind, "Brittle creep in basalt and its application to time-dependent volcano deformation," Earth and Planetary Science Letters, vol. 307, no. 1-2, pp. 71-82, 2011.

[230] D. K. Wang, J. P. Wei, G. Z. Yin, Y. G. Wang, and Z. H. Wen, "Triaxial creep behavior of coal containing gas in laboratory," Procedia Engineering, vol. 26, pp. 1001-1010, 2011.

[231] M. Naumann, U. Hunsche, and O. Schulze, "Experimental investigations on anisotropy in dilatancy, failure and creep of opalinus clay," Physics and Chemistry of the Earth Parts A/B/ C, vol. 32, no. 8-14, pp. 889-895, 2007.

[232] B. S. Yuan, "Application of corrosion resistant air-tight concrete in right line of no. 2 Tiefengshan tunnel," Highway, vol. 7, pp. 199-201, 2006.

[233] H. Wang, W. Z. Chen, X. J. Tan, H. M. Tian, and J. J. Cao, "Development of a new type of foam concrete and its application on stability analysis of large-span soft rock tunnel," Journal of Central South University, vol. 19, no. 11, pp. 3305-3310, 2012.

[234] G. J. Wu, W. Z. Chen, H. M. Tian, S. P. Jia, J. P. Yang, and X. J. Tan, "Numerical evaluation of a yielding tunnel lining support system used in limiting large deformation in squeezing rock," Environmental Earth Sciences, vol. 77, p. $439,2018$.

[235] Foamed Concrete Applications, 2018, http://www. foamedconcrete.co.uk.

[236] M. D. Jalal, A. Tanveer, K. Jagdeesh, and F. Ahmed, "Foam concrete," International Journal of Civil Engineering Research, vol. 8, no. 1, pp. 1-14, 2017, http://www.ripublication. com/ijcer17/ijcerv8n1_01.pdf.

[237] Case Studies for Foam Concrete, 2019, http://www. gsfoamconcrete.co.uk.

[238] K. Ding, S. C. Li, X. Y. Zhou et al., "Effect of filling for top defect of secondary lining of tunnel by foam concrete," Yangtze River, vol. 48, no. 18, pp. 73-77, 2017.

[239] J. Zhang, "Landscape design of tunnel portal-a case in Wulaofeng tunnel of west lake scenic area in Hangzhou," Journal of Hebei Agricultural Sciences, vol. 13, no. 3, pp. 87-89, 2009.

[240] S. Kontoe, L. Zdravkovic, D. M. Potts, and C. O. Menkiti, "Case study on seismic tunnel response," Canadian Geotechnical Journal, vol. 45, no. 12, pp. 1743-1764, 2008.

[241] K. H. Cai and T. Yu, "Treatment scheme and calculation analysis of Shima tunnel collapse," Beifang Jiaotong, vol. 8, pp. 61-65, 2011.

[242] H. G. Deng and C. Cheng, "Closure of abandoned mine lanes with foam concrete," World Mining Express, vol. 34, pp. 18-19, 1992.

[243] F. Alan, H. Mike, and A. David, The stabilisation of Combe Down Stone Mines, Combe Down Stone Mines Project, Dulverton, UK, 2011.

[244] X. J. Tan, W. Z. Chen, H. Y. Liu et al., "A combined supporting system based on foamed concrete and U-shaped steel for underground coal mine roadways undergoing large deformations," Tunnelling and Underground Space Technology, vol. 68, pp. 196-210, 2017.

[245] H. Wen, S. X. Fan, D. Zhang, W. F. Wang, J. Guo, and Q. F. Sun, "Experimental study and application of a novel foamed concrete to yield airtight walls in coal mines," Advances in Materials Science and Engineering, vol. 2018, Article ID 9620935, 2018.

[246] M. X. Zhang, "Study on filling in natural gas special tunnel," Shanghai Gas, vol. 3, pp. 1-4, 2018. 
[247] C. H. Dowding and A. Rozen, "Damage to rock tunnels from earthquake shaking," Journal of Geotechnical and Geoenvironmental Engineering, vol. 104, no. 2, pp. 175-191, 1978.

[248] J. Tohda, H. Yoshimura, and L. M. Li, "Characteristic features of damage to the public sewerage systems in the Hanshin area," Soils and Foundations, vol. 36, pp. 335-347, 1996.

[249] K. Masaru and M. Masakatsu, "Damage to water supply pipelines," Soils and Foundations, vol. 36, pp. 325-333, 1996.

[250] Real Foam Cellular Concrete Applications, 2018, http://www. canadiancellularconcrete.com.

[251] M. Reisi, S. A. Dadvar, and A. Sharif, "Microstructure and mixture proportioning of non-structural foamed concrete with silica fume," Magazine of Concrete Research, vol. 69, no. 23, pp. 1218-1230, 2017.

[252] S.-Y. Chung, C. Lehmann, M. A. Elrahman, and D. Stephan, "Pore characteristics and their effects on the material properties of foamed concrete evaluated using Micro-CT images and numerical approaches," Applied Sciences, vol. 7, no. 6, p. 550, 2017.

[253] B. Šavija and E. Schlangen, "Use of phase change materials (PCMs) to mitigate early age thermal cracking in concrete: theoretical considerations," Construction and Building Materials, vol. 126, pp. 332-344, 2016.

[254] C. Liu, L. Xing, H. W. Liu et al., "Numerical study of bond slip between section steel and recycled aggregate concrete with full replacement ratio," Applied Sciences, vol. 10, no. 3, Article ID 887, 2020.

[255] L. X. Wang, S. S. Xu, J. L. Qiu et al., “Automatic monitoring system in underground engineering construction: review and prospect," Advances in Civil Engineering, Article ID 3697253, 12 pages, 2020.

[256] Z. P. Song, G. L. Shi, B. Y. Zhao, K. M. Zhao, and J. B. Wang, "Study of the stability of tunnel construction based on double-heading advance construction method," Advances in Mechanical Engineering, vol. 12, no. 1, 17 pages, 2020. 